\title{
Intraspecific comparisons of metal bioaccumulation in the juvenile Atlantic silverside Menidia menidia
}

\author{
Jessica Dutton*, Nicholas S. Fisher \\ School of Marine and Atmospheric Sciences, Stony Brook University, Stony Brook, New York 11794-5000, USA
}

\begin{abstract}
We experimentally assessed the uptake, loss and resulting tissue distribution of $\mathrm{Am}, \mathrm{Cd}$, inorganic $\mathrm{Hg}(\mathrm{II})$, methylmercury (MeHg), Se and $\mathrm{Zn}$ in 2 North American populations (Nova Scotia and South Carolina) of juvenile Atlantic silverside Menidia menidia from aqueous and dietary sources using a radiotracer technique. Northern silversides (Nova Scotia) have a higher rate of ingestion and growth compared to their southern (South Carolina) counterparts to overcome a shorter growing season. Uptake rate constants from the dissolved phase were highest for $\mathrm{MeHg}$ and lowest for Cd. Assimilation efficiencies of ingested metals were highest for MeHg (82 to 89\%) and lowest for Am $(0.3$ to $1.9 \%)$. No pronounced difference in metal uptake was noted between the 2 populations, except for $\mathrm{MeHg}$ after aqueous exposure, and Cd after dietary exposure, where South Carolina fish retained more metal. Elimination rate constants did not vary significantly between populations and exposure routes (except for $\mathrm{Hg}$ (II) after a dietary exposure) indicating that both populations process metals at the same rate. The tissue distribution of each metal in the fish varied among metals and exposure routes. Using a metal bioaccumulation model, the calculated steady-state body burden of metal was highest for Zn, and lowest for Am. Calculated body burdens were higher in South Carolina silversides for Am, Cd, and $\mathrm{Zn}$. For all metals except Am, the diet is the dominant exposure route. Of the metals investigated, $\mathrm{MeHg}$ and $\mathrm{Zn}$ in both populations and $\mathrm{Cd}$ in the South Carolina population are expected to biomagnify at this trophic step.
\end{abstract}

KEY WORDS: Metals $\cdot$ Fish $\cdot$ Bioaccumulation $\cdot$ Growth rate $\cdot$ Ingestion rate Resale or republication not permitted without written consent of the publisher

\section{INTRODUCTION}

Understanding metal bioaccumulation in fish is important for evaluating the risk of metal exposure to the fish themselves, their predators, and potentially human consumers of contaminated seafood. Fish, like other aquatic organisms, are exposed to metals via the dissolved phase and their diet. Often, studies using fish only focus on either the dissolved (Jeffree et al. 2006) or dietary (Reinfelder \& Fisher 1994a, Ni et al. 2000, Baines et al. 2002, Mathews \& Fisher 2008a,b) exposure route, and few studies combine the 2 exposure routes to calculate total body burdens (Xu \& Wang 2002, Wang \& Wong 2003, Pickhardt et al. 2006). Studies have shown that diet is the dominant exposure pathway for metals in freshwater and marine fish $(\mathrm{Xu}$ \& Wang 2002, Pickhardt et al. 2006, Mathews \& Fisher 2009). Dietary exposure accounts for 40 to $88 \%$ of inor- ganic $\mathrm{Hg}(\mathrm{Hg}(\mathrm{II})),>68 \%$ of $\mathrm{Cd},>95 \%$ of $\mathrm{Zn}, 97 \%$ of Se, and $>98 \%$ of methylmercury (MeHg) body burden when fish are fed crustacean prey (Xu \& Wang 2002, Pickhardt et al. 2006). While dietary studies have focused on prey choice as an influence on the assimilation efficiency ( $A E_{\text {; }}$ defined as percentage of ingested metal which crosses the gut lining) of various metals, few have investigated the physiological factors governing metal bioaccumulation in fish, including the effects of ingestion rate and growth rate $(\mathrm{Xu} \&$ Wang 2002, Zhang \& Wang 2006).

Previous studies using marine invertebrates (copepods and mussels) indicate that $\mathrm{AE}$ is dependent on ingestion rate: when food is in low supply gut passage time increases, allowing digestive enzymes to solubilize a greater proportion of ingested metal, therefore increasing the AE (Wang \& Fisher 1996, Xu \& Wang 2001). This relationship has also been noted in fish, 
with higher Se and Zn AEs at lower ingestion rates in the mangrove snapper Lutjanus argentimaculatus (Xu \& Wang 2002) and grunt Terapon jarbua (Zhang \& Wang 2006). No concise relationship has been found for $\mathrm{Cd}$, with higher AEs at lower ingestion rates in L. argentimaculatus (Xu \& Wang 2002), but no significant relationship between ingestion rate and $\mathrm{AE}$ in $T$. jarbua (Zhang \& Wang 2006). Prior studies have also shown that growth rate can influence metal concentrations in aquatic animals, with faster growers having lower metal concentrations than slower growers due to somatic growth dilution. Daphnia pulex fed high quality algae labeled with MeHg grew 3.5 times faster than those fed poor quality algae, resulting in somatic growth dilution, and lower steady-state body burdens (Karimi et al. 2007). This has also been noted in Atlantic salmon Salmo salar, with faster growing fish having a lower body burden of Hg (Ward et al. 2010).

The Atlantic silverside Menidia menidia inhabits estuaries, bays and salt marshes along the east coast of North America, from the Gulf of Newfoundland, Canada, to northern Florida, USA (Johnson 1975), and undergoes an annual lifecycle with $<1 \%$ of breeding adults reaching 2 yr old (Conover \& Ross 1982). $M$. menidia is a model organism to investigate the role of ingestion rate and growth rate on the body burden of various metals. There are latitudinal differences in ingestion rate and growth rate throughout the species range, with northern populations having a higher rate of ingestion and growth than southern populations (Conover \& Present 1990, Present \& Conover 1992). This counter-gradient variation evolved to overcome the shorter growing season, and size-selective winter mortality at higher latitudes (Conover \& Present 1990). At the end of the growing season, the body length of M. menidia is the same throughout the species range, indicating that the northern fish grow faster throughout the shorter growing season (Conover \& Present 1990). However, there are trade-offs associated with higher rates of physiological processes, with northern fish experiencing reduced swimming performance, and therefore increased predation pressure (Billerbeck et al. 2001, Lankford et al. 2001). Rates of metal uptake and loss from water and diet, and the resulting body burden, could be significantly different between the 2 endpoints of this species range, due to the documented differences in physiological rates in juvenile M. menidia.

To assess the effects of different ingestion and growth rates on metal bioaccumulation, we conducted a series of controlled laboratory pulse-chase experiments to investigate the rate of metal (Am, Cd, $\mathrm{Hg}$ (II), MeHg, $\mathrm{Se}$, and $\mathrm{Zn}$ ) uptake and loss after aqueous and dietary exposure, and the resulting tissue distribution, in 2 populations of the Atlantic silverside (Nova Scotia and
South Carolina; representing populations near the northern and southern limit of the species range) using a radiotracer technique. For dietary exposures, radiolabeled diatoms (Thalassiosira pseudonana) were fed to invertebrate prey (brine shrimp Artemia franciscana nauplii), which were then fed to juvenile Atlantic silversides. Calculated kinetic parameters describing metal bioaccumulation in these fish were entered into a biokinetic model (Wang et al. 1996) to calculate the steady-state metal concentration in both populations, the primary uptake route for each metal, and the potential for each metal to biomagnify at this trophic step.

Metals were chosen based on their chemical characteristics and environmental concern. Se and $\mathrm{Zn}$ are biologically essential, whereas $\mathrm{Am}, \mathrm{Cd}$ and $\mathrm{Hg}$ are non-essential metals. We chose metals with varying binding preferences for sulfur, nitrogen, and oxygen, which influences their protein association. Am is a Class A (oxygen-seeking) metal, Hg a Class B (sulfurseeking) metal, and $\mathrm{Cd}$ and $\mathrm{Zn}$ are borderline metals (Nieboer \& Richardson 1980). These metals have a wide range of AEs in herbivores (Reinfelder \& Fisher 1991, Wang \& Fisher 1998), which has been correlated with the cytoplasmic distribution of metals in phytoplankton food (Reinfelder \& Fisher 1991, 1994b), and this, in turn, can affect the assimilation efficiency of metals in fish when fed crustacean prey (Reinfelder \& Fisher 1994a). Cd, Hg(II), MeHg, Se and $\mathrm{Zn}$ are found at elevated levels in coastal water (Kennish 1997). $\mathrm{MeHg}$ is of particular concern due to the associated health risks in humans (Guallar et al. 2002, Chang et al. 2008), resulting in seafood consumption advisories. Am is a synthetic actinide, produced from the decay of ${ }^{241} \mathrm{Pu}$, and has been released as nuclear waste into coastal water and from nuclear weapons fallout (Park et al. 1983). Am is a particle-reactive trivalent cation, which remains sorbed to the cell surface and not transported into the cell (Reinfelder \& Fisher 1991). It is expected that this element behaves similarly to many other particle-reactive nonessential trivalent metals, such as many of the rare earth elements.

\section{MATERIALS AND METHODS}

Experimental conditions. All experiments were carried out in $0.2 \mu \mathrm{m}$ sterile filtered (Millipak 200, Millipore) Southampton seawater (SHSW), collected 5 miles offshore of Southampton (Long Island, NY, USA; salinity $=34, \mathrm{pH} 7.9$, dissolved organic carbon $=115 \pm$ $19 \mu \mathrm{M} C$ [mean $\pm \mathrm{SD}, \mathrm{n}=3]$ ). Background metal concentrations were analyzed by ICP-MS at the Trace Element Analysis Core Facility, Dartmouth College (total $\mathrm{Hg}$ ), and Rutgers Inorganic Analytical Laboratory, Rut- 
gers University (Cd, Se, Zn). Phytoplankton and invertebrate prey were held at $18 \pm 0.5^{\circ} \mathrm{C}$, and fish at $21 \pm$ $0.5^{\circ} \mathrm{C}$. All experimental organisms were held under a $14 \mathrm{~h}$ light:10 h dark cycle.

Fish maintenance and acclimation. Juvenile F1 and F2 generation laboratory-reared Atlantic silversides Menidia menidia from Nova Scotia $\left(44^{\circ} \mathrm{N}\right)$ and South Carolina $\left(33^{\circ} \mathrm{N}\right)$ were used in this study. Both populations were of the same age (approximately 2 mo). Nova Scotia fish were $59 \pm 5 \mathrm{~mm}$ (mean \pm SD) long, with a mean wet weight (wt) of $0.9 \pm 0.18 \mathrm{~g}$, while South Carolina fish were $38 \pm 5 \mathrm{~mm}$ long, with a mean wet wt of $0.32 \pm 0.1 \mathrm{~g}$. Fish were spawned and raised at the Flax Pond Marine Laboratory (Oldfield, New York) from field-collected fish following a protocol described elsewhere (Conover \& Present 1990, Present \& Conover 1992) and transferred to our laboratory at least $3 \mathrm{wk}$ before the start of experiments where they were acclimated to SHSW, and fed a daily diet of brine shrimp (Artemia franciscana) nauplii. Brine shrimp nauplii was the chosen prey species because it is representative of crustacean zooplankton, and studies have shown that Atlantic silversides survive best when fed this prey in the laboratory (Beck \& Poston 1980). At least $4 \mathrm{~d}$ prior to each experiment, 8 to 10 fish from each population were transferred to individual containers with $600 \mathrm{ml}$ SHSW and an airstone to acclimate to experimental conditions. Fish were starved for $24 \mathrm{~h}$ prior to experiments to allow for total gut clearance. The experimental temperature was set at $21^{\circ} \mathrm{C}$ because both populations experience it during the spawning season in the wild (Conover \& Present 1990), and fish are held at this temperature at the Flax Pond Marine Laboratory.

Fish exposure to aqueous metal. Radioisotopes were added to SHSW and allowed to equilibrate for at least $6 \mathrm{~h}$. Atlantic silversides from each population ( $\mathrm{n}=8$ to 10) were exposed to $250 \mathrm{ml}$ of radiolabeled SHSW in individual containers. Radioisotope additions per fish were $5.9 \mathrm{kBq}{ }^{241} \mathrm{Am}, 5.4 \mathrm{kBq}{ }^{109} \mathrm{Cd}$, $1.6 \mathrm{kBq}{ }^{203} \mathrm{Hg}(\mathrm{II})$, $0.6 \mathrm{kBq} \mathrm{MeHg}$, and $13 \mathrm{kBq}{ }^{65} \mathrm{Zn}$. This corresponds to the following metal concentrations: $0.98 \mathrm{nM}{ }^{241} \mathrm{Am}$, $0.27 \mathrm{nM}{ }^{109} \mathrm{Cd}, 0.23 \mathrm{nM}{ }^{203} \mathrm{Hg}(\mathrm{II}), 0.25 \mathrm{nM} \mathrm{MeHg}$, and $3.00 \mathrm{nM}^{65} \mathrm{Zn}$. Exposure time was $12 \mathrm{~h}$ for Am and $\mathrm{MeHg}$, and $36 \mathrm{~h}$ for $\mathrm{Cd}, \mathrm{Hg}(\mathrm{II})$, and $\mathrm{Zn}$. Exposure period varied between metals to allow an exposure time sufficient to radiolabel the fish while minimizing the likelihood of metal loss from the fish during this uptake period. ${ }^{75} \mathrm{Se}$ uptake from the dissolved phase was not investigated because aqueous selenite shows little reactivity for fish (Besser et al. 1993). Fish were not fed during the labeling period, so dissolved metal was the only source for the fish. At the end of the exposure period fish received two $30 \mathrm{~s}$ rinses in filtered unlabeled SHSW to remove excess radioisotope, and were immediately radioassayed. They were then re- turned to individual containers containing $600 \mathrm{ml}$ unlabeled SHSW to depurate for $6 \mathrm{~d}$, during which they were fed unlabeled brine shrimp nauplii. Radioactivity in the fish was analyzed at regular intervals throughout the first $24 \mathrm{~h}$, and then daily for another $5 \mathrm{~d}$. Fish were fed brine shrimp nauplii daily and underwent regular water changes throughout the depuration period. After $6 \mathrm{~d}$, the fish were euthanized in $450 \mathrm{ppm}$ MS222 (tricaine methane sulphonate), and dissected into 3 body compartments: head (including gills), viscera, and body (skeleton, fillet, fins, and skin). Tissue samples were immediately radioassayed, dried in an oven at $60^{\circ} \mathrm{C}$ for $24 \mathrm{~h}$, and the dry wt recorded. Not all fish initially exposed to the radiolabeled SHSW survived throughout depuration, therefore only data from fish which survived the whole experiment are shown in the results ( $\mathrm{n}=4$ to 9 per population). No toxic effects of metal exposure (death, excess mucus production, abnormal swimming behavior) were observed during the metal uptake period. Juvenile Atlantic silversides are very sensitive to handling (Present \& Conover 1992), which this mortality is attributed to.

Fish exposure to dietary metal. The marine diatom Thalassiosira pseudonana was uniformly radiolabeled for $4 \mathrm{~d}$ with radioisotopes in $1 \mathrm{l}$ SHSW, amended with nutrients at f/2 concentrations (Guillard \& Ryther 1962), but modified so no $\mathrm{Cu}, \mathrm{Zn}$, and EDTA were added. Radioisotope additions were $79 \mathrm{kBq}{ }^{241} \mathrm{Am}, 216 \mathrm{kBq}$ ${ }^{109} \mathrm{Cd}, 71 \mathrm{kBq}{ }^{203} \mathrm{Hg}(\mathrm{II}), 61 \mathrm{kBq} \mathrm{MeHg}, 55 \mathrm{kBq}{ }^{75} \mathrm{Se}$, and $183 \mathrm{kBq}^{65} \mathrm{Zn}$. This corresponds to $3.50 \mathrm{nM}^{241} \mathrm{Am}, 0.66$ $n M{ }^{109} \mathrm{Cd}, 3.00 \mathrm{nM}{ }^{203} \mathrm{Hg}(\mathrm{II}), 2.00 \mathrm{nM} \mathrm{MeHg}, 3.96 \mathrm{nM}$ ${ }^{75} \mathrm{Se}$, and $3.32 \mathrm{nM}^{65} \mathrm{Zn}$. At the end of uptake, algal cells were filtered through a $3 \mu \mathrm{m}$ polycarbonate membrane, rinsed with unlabeled SHSW to remove excess radioisotope, resuspended in $500 \mathrm{ml}$ non-radiolabeled SHSW to attain a cell density of $1 \times 10^{6}$, and allowed to equilibrate for $4 \mathrm{~h}$. Approximately 2000 brine shrimp (Artemia franciscana) nauplii were added to the algal suspension and allowed to feed for $20 \mathrm{~h}$. Nauplii were then filtered through a $10 \mu \mathrm{m}$ polycarbonate membrane, rinsed to remove excess radioactivity from the carapace, and added to $50 \mathrm{ml}$ unlabeled SHSW to make a brine shrimp slurry. One ml of slurry (approximately 60 brine shrimp nauplii) was presented to 8 fish from each population, and these were allowed to feed for $45 \mathrm{~min}$. No feces were produced during the feeding period. After feeding, fish were removed from their container, and immediately radioassayed. Fish were then returned to individual containers with $600 \mathrm{ml}$ unlabeled SHSW and fed unlabeled brine shrimp nauplii to purge their guts of unassimilated radiolabeled food. At each time point, feces were collected and radioassayed to monitor the gut passage time of unassimilated radiolabeled food. The $6 \mathrm{~d}$ depuration, euthanization, and dissection procedure followed that 
described previously. Only data from fish that survived the entire experimental period are shown $(\mathrm{n}=5$ to 8 per population).

Radioisotopes and radioanalysis. ${ }^{109} \mathrm{Cd}\left(t_{1 / 2}=463.3 \mathrm{~d}\right)$ and ${ }^{65} \mathrm{Zn}\left(t_{1 / 2}=244.1 \mathrm{~d}\right)$, both dissolved in $0.1 \mathrm{~N} \mathrm{HCl}$, were purchased from Los Alamos National Laboratory, ${ }^{241} \mathrm{Am}\left(t_{1 / 2}=432.7 \mathrm{yr}\right.$, dissolved in $\left.3 \mathrm{NHNO}_{3}\right)$ was purchased from Amersham, ${ }^{75} \mathrm{Se}\left(t_{1 / 2}=119.8 \mathrm{~d}\right.$, as selenite, dissolved in $0.1 \mathrm{~N} \mathrm{HCl}$ ) was purchased from Isotope Products, and ${ }^{203} \mathrm{Hg}(\mathrm{II})\left(t_{1 / 2}=46.6 \mathrm{~d}\right.$, dissolved in $1 \mathrm{~N}$ $\mathrm{HCl})$ was obtained from Georgia State University. $\mathrm{MeHg}\left(\mathrm{CH}_{3}{ }^{203} \mathrm{Hg}(\mathrm{II})\right)$, held in deionized water, was synthesized in our laboratory from $\mathrm{Hg}$ (II) using a method described by Imura et al. (1971), Rouleau \& Block (1997), and Bancon-Montigny et al. (2004). Experimental radioisotope additions were in $\mu$ l quantities, and equimolar volumes of sodium hydroxide $(\mathrm{NaOH})$ were added to neutralize the acid added during radiolabeling. The $\mathrm{pH}$ was monitored and unaffected by the radioisotope addition. ${ }^{241} \mathrm{Am}$ and ${ }^{75} \mathrm{Se}$, and ${ }^{109} \mathrm{Cd}$ and ${ }^{65} \mathrm{Zn}$ were double-labeled (2 isotopes in the same experimental container), while ${ }^{203} \mathrm{Hg}$ (II) and MeHg were single-labeled.

Radioactivity in the fish was assayed non-invasively using a Canberra deep-well NaI(Tl) $\gamma$-detector, allowing the same fish to be analyzed throughout depuration, therefore reducing biological variability. Counting times did not exceed 5 min to reduce stress on the fish, yet allowed propagated counting errors typically $\leq 5 \%$ to be obtained. However, propagated counting errors could reach $25 \%$ by the end of depuration if most of the radioactivity was lost and counts were close to background level. Water, feces, and dissected fish tissue samples were radioassayed using an inter-calibrated LKB Pharmacia-Wallac 1282 CompuGamma CS gamma counter for either $5 \mathrm{~min}\left({ }^{241} \mathrm{Am},{ }^{109} \mathrm{Cd},{ }^{65} \mathrm{Zn}\right)$, or $10 \mathrm{~min}\left({ }^{203} \mathrm{Hg},{ }^{75} \mathrm{Se}\right)$. All sample counts were adjusted for background radioactivity and radioactive decay. The $\gamma$-emissions of ${ }^{109} \mathrm{Cd},{ }^{241} \mathrm{Am},{ }^{203} \mathrm{Hg},{ }^{75} \mathrm{Se}$, and ${ }^{65} \mathrm{Zn}$ were detected at 22, 59.5, 279, 400, and $1115 \mathrm{keV}$, respectively.

Modeling metal bioaccumulation in fish. The bioaccumulation of metals in fish, like other aquatic organisms, can be defined as a balance between metal uptake and loss from aqueous and dietary sources. This was originally described by Thomann (1981), and then modified by Wang et al. (1996) and Reinfelder et al. (1998). This model has been successfully tested using marine invertebrates (Fisher et al. 1996, 2000, Wang \& Fisher 1998), and more recently freshwater and marine fish (Wang \& Wong 2003, Pickhardt et al. 2006). Kinetic parameters derived from laboratory experiments can be used to model predicted values in the field. Under steady-state conditions the equation is as follows:

$$
C_{\mathrm{ss}}=\left(k_{\mathrm{u}} \cdot C_{\mathrm{w}}\right) /\left(g+k_{\mathrm{ew}}\right)+\left(\mathrm{AE} \cdot \mathrm{IR} \cdot C_{\mathrm{f}}\right) /\left(g+k_{\mathrm{ef}}\right)
$$

where $C_{\mathrm{ss}}$ is the steady-state concentration of metal in an organism $\left(\mu \mathrm{g} \mathrm{g}^{-1}\right), k_{\mathrm{u}}$ is the uptake rate constant from the dissolved phase $\left(\mathrm{ml} \mathrm{g}^{-1} \mathrm{~d}^{-1}\right), C_{\mathrm{w}}$ is the dissolved metal concentration in water $\left(\mu \mathrm{g} \mathrm{ml}^{-1}\right), g$ is the growth rate constant $\left(\mathrm{d}^{-1}\right), k_{\text {ew }}$ is the loss rate constant after dissolved exposure $\left(\mathrm{d}^{-1}\right), \mathrm{AE}$ is the assimilation efficiency of ingested metal (\%), IR is the ingestion rate $\left(\mathrm{g} \mathrm{g} \mathrm{g}^{-1} \mathrm{~d}^{-1}\right), C_{\mathrm{f}}$ is the metal concentration in food $(\mu \mathrm{g}$ $\mathrm{g}^{-1}$ ), and $k_{\text {ef }}$ is the loss rate constant after dietary exposure $\left(\mathrm{d}^{-1}\right)$.

Radioactivity in fish at the end of uptake was used to calculate $k_{\mathrm{u}}$, by dividing radioactivity in individual fish $\left(\mathrm{g}^{-1}\right.$ dry wt) by radioactivity in $\mathrm{ml}^{-1}$ water and by time (d). AE and $k_{\mathrm{e}}$ values were calculated by fitting an exponential regression between the $48 \mathrm{~h}$ and $144 \mathrm{~h}$ depuration time points. The AE was determined to be the $y$-intercept, and $k_{\mathrm{e}}$ was the slope of the curve. The biological half-life $\left(t b_{1 / 2}\right)$ of a metal in the fish after aqueous and dietary exposure is defined as the time it takes for $50 \%$ of the metal to be excreted, and is calculated as:

$$
t b_{1 / 2}=\ln 2 / k_{\mathrm{e}}
$$

We used food consumption data from Billerbeck et al. (2000) to calculate the weight-specific ingestion rate (food consumption divided by dry wt of fish), resulting in an ingestion rate of $0.58 \mathrm{~g} \mathrm{~g}^{-1} \mathrm{~d}^{-1}$ for Nova Scotia silversides and $0.37 \mathrm{~g} \mathrm{~g}^{-1} \mathrm{~d}^{-1}$ for South Carolina silversides. Growth rate constants were calculated using the following allometric relationship between length and weight:

$$
W=a \cdot L^{b}
$$

where $W$ is the fish weight $(\mathrm{g}), L$ is the fish length $(\mathrm{cm})$, and $a$ and $b$ are allometric coefficients $(a=0.006, b=$ 3.023 ; Jessop 1983). $L$ values are the average length of fish used in this study (Nova Scotia $5.9 \mathrm{~cm}$, South Carolina $3.8 \mathrm{~cm}$ ). The growth rate relationship can be calculated from the derivative of the allometric equation with respect to time, described as follows:

$$
\mathrm{d} W / \mathrm{d} t=a \cdot b \cdot L^{b-1} \cdot(\mathrm{d} L / \mathrm{d} t)
$$

For $\mathrm{d} L / \mathrm{d} t$ we applied $0.082 \mathrm{~cm} \mathrm{~d}^{-1}$ for Nova Scotia silversides (Jessop 1983), and $0.027 \mathrm{~cm} \mathrm{~d}^{-1}$ for South Carolina silversides (Sosebee 1991). The calculated daily growth rate $\left(0.051 \mathrm{~g} \mathrm{~d}^{-1}\right.$ Nova Scotia, $0.007 \mathrm{~g} \mathrm{~d}^{-1}$ South Carolina) was then divided by the average wet wt of the fish used in this study (Nova Scotia $0.9 \mathrm{~g}$, South Carolina $0.32 \mathrm{~g}$ ) to calculate a growth rate constant of $0.057 \mathrm{~d}^{-1}$ for Nova Scotia silversides and $0.022 \mathrm{~d}^{-1}$ for South Carolina silversides.

The $C_{\mathrm{w}}$ values used were background metal concentrations in SHSW (Cd, Hg, Se, Zn) or literature values for Am (Cochran et al. 1987), and MeHg (Hammer- 
schmidt \& Fitzgerald 2006), and were as follows: $1.9 \times 10^{-15} \mathrm{ug} \mathrm{m}^{-1} \mathrm{Am}, 0.17 \mathrm{ng}$ $\mathrm{ml}^{-1} \mathrm{Cd}, 3.3 \mathrm{pg} \mathrm{ml}^{-1} \mathrm{Hg}, 0.03 \mathrm{pg} \mathrm{ml}^{-1}$ $\mathrm{MeHg}, 0.03 \mathrm{ng} \mathrm{ml}^{-1} \mathrm{Se}$, and $8.7 \mathrm{ng} \mathrm{ml}^{-1}$ Zn. $C_{\mathrm{f}}$ values for zooplankton (dry wt) were obtained from the literature, and are as follows: $2.5 \mu \mathrm{g} \mathrm{g}^{-1} \mathrm{Cd}, 1.3 \mu \mathrm{g} \mathrm{g}^{-1}$ Se, and $167 \mathrm{\mu g} \mathrm{g}^{-1} \mathrm{Zn}$ (Fisher et al. 2000). We used a mean total $\mathrm{Hg}$ value of $0.22 \mathrm{ug} \mathrm{g}^{-1}$ (IAEA 2004). $\mathrm{MeHg}$ accounts for $75 \%$ of total $\mathrm{Hg}$ in crustacean zooplankton (Francesconi \& Lenanton 1992), so we applied a $C_{\mathrm{f}}$ value of $0.165 \mu \mathrm{g} \mathrm{g}^{-1}$ for $\mathrm{MeHg}$, and $0.055 \mu \mathrm{g}$ $\mathrm{g}^{-1}$ for $\mathrm{Hg}(\mathrm{II})$. The Am $C_{\mathrm{f}}$ was calculated by multiplying the $C_{\mathrm{w}}$ by the concentration factor of Am in zooplankton (4000, IAEA 2004) to obtain a value of

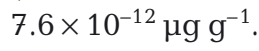

Eq. (1) can be rearranged to calculate the relative importance of dissolved versus dietary exposure routes to the steady-state body burden of metal using the following equation:

$$
R=\left[\left(\mathrm{AE} \cdot \mathrm{IR} \cdot C_{\mathrm{f}}\right) /\left(g+k_{\mathrm{ef}}\right)\right] / C_{\mathrm{SS}} \cdot 100
$$

where $R$ is the percentage attributed to dietary exposure. Eq. (1) can also be rearranged to calculate the trophic transfer factor (TTF), which indicates the potential for a metal to biomagnify at this trophic step based upon the ratio of metal in the predator to metal in the prey. TTF is calculated as follows:

$$
\mathrm{TTF}=(\mathrm{AE} \cdot \mathrm{IR}) /\left(g+k_{\mathrm{ef}}\right)
$$

A TTF $>1$ indicates that a metal is likely to biomagnify at this trophic step, while a TTF $<1$ indicates that biomagnification is unlikely (Reinfelder et al. 1998).

\section{RESULTS}

\section{Uptake of metals from the dissolved phase}

For all metals examined, most of the added metal remained in the dissolved phase (that is, not taken up by the fish) throughout the exposure period. The percentage of added metal associated with fish at the end of exposure was 0.06 to $0.17 \%$ for Am, 0.04 to $0.09 \%$ for $\mathrm{Cd}$, 1.1 to $2.1 \%$ for $\mathrm{Hg}(\mathrm{II}), 31$ to $33 \%$ for $\mathrm{MeHg}$, and 0.17 to $0.22 \%$ for $\mathrm{Zn}$. The calculated uptake rate constants from the dissolved phase $\left(k_{\mathrm{u}}\right)$ were consistently higher in the South Carolina population (Table 1). $k_{\mathrm{u}}$ values $\left(\mathrm{ml} \mathrm{g}^{-1} \mathrm{~d}^{-1}\right)$ were highest for MeHg (1155 and 4375), followed by $\mathrm{Hg}$ (II) (15 and 17), Am (11 and 13), Zn (1.9 and 5), and Cd (0.8 and 1.3). $k_{\mathrm{u}}$ values were 1.2, 1.6, 1.1, 3.8, and 2.6 times higher in South Carolina silversides for
Am, Cd, Hg(II), MeHg, and Zn respectively. Am and $\mathrm{Hg}$ (II) $k_{\mathrm{u}}$ values showed no significant differences in the rate of metal uptake between the 2 populations ( $t$-test, $\mathrm{p}>0.05)$, while there was a significant difference for $\mathrm{Cd}, \mathrm{MeHg}$ and $\mathrm{Zn}(\mathrm{p}<0.01)$. Both populations had higher $k_{\mathrm{u}}$ values for $\mathrm{MeHg}$ than $\mathrm{Hg}(\mathrm{II})$. Calculated dry wt concentration factors (CF), defined as dpm (disintegrations per minute) $\mathrm{g}^{-1}$ fish divided by dpm $\mathrm{ml}^{-1}$ dissolved in seawater, show that all metals were more enriched in fish than in the surrounding water $(\mathrm{CF}>1)$, and South Carolina silversides had consistently higher $\mathrm{CF}$ values for all metals. South Carolina CF values $($ mean $\pm 1 \mathrm{SE})$ were $6.4 \pm 0.4$ for $\mathrm{Am}, 2.0 \pm 0.2$ for $\mathrm{Cd}$, $25 \pm 2.7$ for $\mathrm{Hg}(\mathrm{II}), 2155 \pm 247$ for $\mathrm{MeHg}$, and $7.4 \pm 1.2$ for Zn. Nova Scotia CF values were $5.7 \pm 0.7$ for Am, $1.2 \pm 0.1$ for $\mathrm{Cd}, 22 \pm 2.7$ for $\mathrm{Hg}(\mathrm{II}), 569 \pm 142$ for $\mathrm{MeHg}$, and $2.8 \pm 0.1$ for Zn. Dry wt CFs can be converted to wet wt CFs by dividing the former by 4.5 (dry wt is $22 \%$ of the wet wt value for Menidia menidia).

After aqueous exposure in SHSW, depuration curves indicated a rapid elimination of metal within the first $24 \mathrm{~h}$, and then slower physiological turnover for the following $5 \mathrm{~d}$ (Fig. 1). After $24 \mathrm{~h}$ of depuration the percentages of metal eliminated were as follows: $34 \%$ Am, $23 \% \mathrm{Cd}, 24 \% \mathrm{Hg}(\mathrm{II}), 5 \% \mathrm{MeHg}$, and $20 \% \mathrm{Zn}$ from Nova Scotia silversides, and $46 \% \mathrm{Am}, 39 \% \mathrm{Cd}$, $26 \% \mathrm{Hg}(\mathrm{II}), 13 \% \mathrm{MeHg}$, and $40 \%$ Zn from South Carolina silversides. South Carolina silversides consistently retained a lower percentage of the initial metal body burden throughout depuration. At the end of $6 \mathrm{~d}$ depuration, the percentages of initial metal remaining were $46 \% \mathrm{Am}, 61 \% \mathrm{Cd}, 51 \% \mathrm{Hg}(\mathrm{II}), 92 \% \mathrm{MeHg}$ and $59 \% \mathrm{Zn}$ in Nova Scotia silversides, and $44 \%$ Am, $43 \%$ $\mathrm{Cd}, 47 \% \mathrm{Hg}(\mathrm{II}), 79 \% \mathrm{MeHg}$, and $38 \% \mathrm{Zn}$ in South Carolina silversides (Fig. 1). Efflux rate constants after 


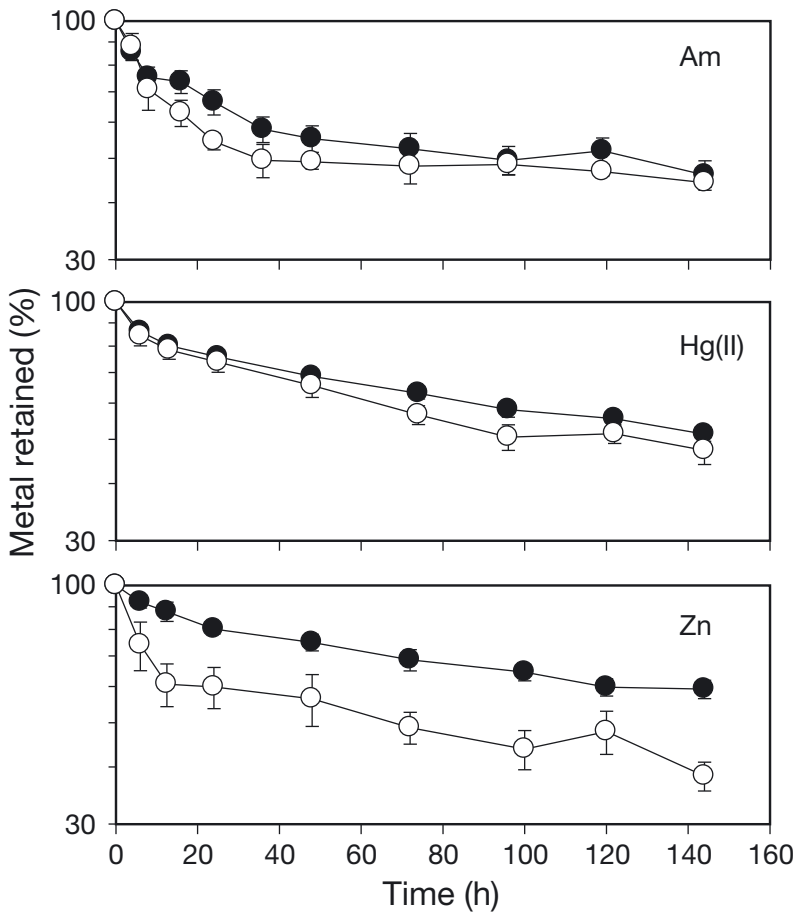

aqueous exposure $\left(k_{\mathrm{ew}}\right)$ are given in Table 1. For Nova Scotia silversides, the efflux rate constant $\left(\mathrm{d}^{-1}\right)$ of $\mathrm{Hg}(\mathrm{II})$ $(0.071)>\mathrm{Zn}(0.061)>\mathrm{Cd}(0.052)>\mathrm{Am}(0.038)>\mathrm{MeHg}$ (0.006). For South Carolina silversides, Cd (0.076) = $\mathrm{Hg}$ (II) (0.075) > Zn (0.056) > Am (0.023) > MeHg (0.014). No significant difference between $k_{\text {ew }}$ for the 2 populations was noted except for MeHg $(\mathrm{p}<0.05)$.

\section{Uptake of metals from diet}

In both silverside populations, AEs for MeHg greatly exceeded those for all other metals. For Nova Scotia silversides, AE was highest for $\mathrm{MeHg}(89 \%)$, followed by Zn (24\%), Cd (15\%), Se (10\%), Hg(II) (8\%), and lowest for Am (0.3\%). For South Carolina silversides AE was highest for MeHg (82\%), followed by Cd (39\%), Zn $(29 \%), \operatorname{Hg}(\mathrm{II})(15 \%)$, Se $(13 \%)$, and lowest for Am $(1.9 \%)$ (Table 2$)$. The AEs for Am were given as percentage remaining after $48 \mathrm{~h}$ of metal loss; exponential regressions could not be fitted to the data due to near complete elimination of the radioisotope. The AEs for $\mathrm{MeHg}$, Se, and $\mathrm{Zn}$ are similar for the 2 populations, but the slight difference in MeHg AEs was found to be statistically significant $(t$-test, $\mathrm{p}<0.05)$. South Carolina silversides assimilated 6.3 times more Am, 2.6 times more Cd (both significant, $\mathrm{p}<0.05$ ), and 1.9 times more $\mathrm{Hg}$ (II) (not significant, $\mathrm{p}>0.05$ ) than Nova Scotia silversides. When comparing the $2 \mathrm{Hg}$ species, Nova Scotia and South Carolina silversides assimilated 11 times and 5.5 times more $\mathrm{MeHg}$ than $\mathrm{Hg}(\mathrm{II})$, respectively.



Fig. 1. Menidia menidia. Metal retention in Atlantic silversides from Nova Scotia and South Carolina after aqueous exposure in Southampton seawater ( $\mathrm{n}=4$ to 9 per population). Retention is expressed as percent of initial body burden after exposure. Values represent means $\pm 1 \mathrm{SE}$

After feeding, all metals were eliminated from both silverside populations following a 2-compartment loss pattern: the rapid loss during the first several $\mathrm{h}$ corresponded to defecation of unassimilated metal, and the slower loss over the remaining depuration period corresponded to physiological turnover of metal (Fig. 2). Within the first $24 \mathrm{~h}, 99.5 \% \mathrm{Am}, 85 \% \mathrm{Cd}, 88 \% \mathrm{Hg}(\mathrm{II})$, $10 \% \mathrm{MeHg}, 87 \% \mathrm{Se}$, and $76 \% \mathrm{Zn}$ was lost from the Nova Scotia population, and 98.6\% Am, $63 \%$ Cd, $86 \%$ $\mathrm{Hg}(\mathrm{II}), 18 \% \mathrm{MeHg}, 83 \% \mathrm{Se}$, and $70 \% \mathrm{Zn}$ was lost from the South Carolina population. At the end of $6 \mathrm{~d}$ depuration, the percentages of initial metal remaining were $0.3 \% \mathrm{Am}, 11 \% \mathrm{Cd}, 5 \% \mathrm{Hg}(\mathrm{II}), 84 \% \mathrm{MeHg}, 6 \% \mathrm{Se}$, and $17 \%$ Zn for Nova Scotia fish, and $1.2 \%$ Am, $30 \%$ Cd, $4 \%$ $\mathrm{Hg}(\mathrm{II}), 76 \% \mathrm{MeHg}, 7 \% \mathrm{Se}$, and $22 \% \mathrm{Zn}$ for South Carolina fish (Fig. 2). Efflux rate constants after dietary exposure $\left(k_{\text {ef }}\right)$ varied by metal, and except for $\mathrm{Hg}(\mathrm{II})$, did not vary between the 2 populations (Table 2). For the Nova Scotia population, the efflux rate $\left(\mathrm{d}^{-1}\right)$ of Se $(0.109)>$ $\mathrm{Hg}(\mathrm{II})(0.086)>\mathrm{Cd}(0.073)>\mathrm{Zn}(0.058)>\mathrm{MeHg}$ (0.011), and for the South Carolina population, $\mathrm{Hg}$ (II) (0.194) $>\mathrm{Se}$ $(0.105)>\mathrm{Cd}(0.052)=\mathrm{Zn}(0.051)>\mathrm{MeHg}(0.013)$.

\section{Tissue distributions and corresponding metal concentrations}

Fig. 3 shows the tissue distribution (as percentage of total dpm in whole fish) of $\mathrm{Am}, \mathrm{Cd}, \mathrm{Hg}(\mathrm{II}), \mathrm{MeHg}$, and $\mathrm{Zn}$ in Atlantic silversides at the end of depuration after aqueous exposure in SHSW. Tissue distribution varied 
Table 2. Menidia menidia. Assimilation efficiencies (AE) and efflux rate constants $\left(k_{\mathrm{ef}}\right)$ in Atlantic silversides from Nova Scotia (NS) and South Carolina (SC) after feeding on brine shrimp (Artemia franciscana) nauplii. Statistically significant differences (by $t$-test) between kinetic parameters and the 2 populations are represented by ${ }^{*}(\mathrm{p}<0.05)$. $\mathrm{n}=5$ to 8 per population; nd: not determined

\begin{tabular}{|c|c|c|c|c|c|c|c|}
\hline & \multirow[t]{2}{*}{ Population } & \multicolumn{3}{|c|}{$\longrightarrow \mathrm{AE}(\%)-$} & \multicolumn{3}{|c|}{$-k_{\text {ef }}\left(\mathrm{d}^{-1}\right)$} \\
\hline & & Mean & SE & Range & Mean & $\mathrm{SE}$ & Range \\
\hline \multirow[t]{2}{*}{$\mathrm{Am}$} & NS & $0.3^{*}$ & 0.06 & $0.13-0.7$ & nd & nd & nd \\
\hline & $\mathrm{SC}$ & $1.9^{*}$ & 0.70 & $0.21-5.0$ & nd & nd & nd \\
\hline \multirow[t]{2}{*}{$\mathrm{Cd}$} & NS & $15^{*}$ & 3 & $5-28$ & 0.073 & 0.017 & $0.043-0.155$ \\
\hline & $\mathrm{SC}$ & $39^{*}$ & 10 & $7-54$ & 0.052 & 0.009 & $0.026-0.092$ \\
\hline \multirow[t]{2}{*}{$\operatorname{Hg}(\mathrm{II})$} & NS & 8 & 2 & $3.2-13$ & 0.086 & 0.014 & $0.040-0.139$ \\
\hline & $\mathrm{SC}$ & 15 & 3 & $7.6-26$ & 0.194 & 0.055 & $0.038-0.455$ \\
\hline \multirow[t]{2}{*}{$\mathrm{MeHg}$} & NS & $89^{*}$ & 0.8 & $86-92$ & 0.011 & 0.001 & $0.007-0.013$ \\
\hline & $\mathrm{SC}$ & $82^{*}$ & 4 & $68-94$ & 0.013 & 0.002 & $0.006-0.017$ \\
\hline \multirow[t]{2}{*}{$\mathrm{Se}$} & NS & 10 & 0.8 & $8-14$ & 0.109 & 0.008 & $0.081-0.140$ \\
\hline & $\mathrm{SC}$ & 13 & 1.5 & $9-18$ & 0.105 & 0.017 & $0.064-0.164$ \\
\hline \multirow[t]{2}{*}{ Zn } & NS & 24 & 4 & $11-39$ & 0.058 & 0.008 & $0.041-0.083$ \\
\hline & $\mathrm{SC}$ & 29 & 6 & $15-61$ & 0.051 & 0.003 & $0.039-0.062$ \\
\hline
\end{tabular}

by metal, but apart for Cd, did not vary between the 2 silverside populations for each metal. Am and $\mathrm{Hg}(\mathrm{II})$ were mainly associated with the head (64 to $69 \%$ Am, 49 to $55 \% \mathrm{Hg}(\mathrm{II}))$, whereas $\mathrm{Zn}$ was distributed between the head (37 to $40 \%$ ) and body (44\%). Am was the only metal to show no association with the viscera (0 to $1 \%$ ). $\mathrm{MeHg}$ was predominantly associated with the body $(70$ to $72 \%$ ). Cd had a higher association with the viscera in Nova Scotia silversides (47\%) than in South Carolina sil- versides (32\%), whereas South Carolina fish had a greater percentage associated with the body (42\% versus $30 \%$ ).

Fig. 4 shows the tissue distribution (as percentage of total dpm in whole fish) of $\mathrm{Cd}, \mathrm{Hg}$ (II), $\mathrm{MeHg}$, Se, and Zn in Atlantic silversides at the end of depuration after feeding on radiolabeled brine shrimp nauplii. Tissue distribution for Am could not be determined due to near complete elimination of the radioisotope. Tissue partitioning varied by metal, and except for $\mathrm{Hg}(\mathrm{II})$, there was no difference in the body partitioning of each metal between the 2 populations. $\mathrm{Cd}$ and $\mathrm{MeHg}$ were predominantly associated with the body (80 to $84 \% \mathrm{Cd}, 51$ to $57 \% \mathrm{MeHg}$ ), whereas Zn was mainly associated with the head (49 to $52 \%$ ). Se was mainly distributed between the head (44 to $45 \%$ ) and body (41 to $44 \%$ ). The tissue distribution of $\mathrm{Hg}(\mathrm{II})$ varied significantly between the 2 populations: the percentage associated with the body was higher in Nova Scotia fish $(67 \%)$ than in South Carolina fish (15\%), while the percentage associated with the viscera was higher in South Carolina fish $(72 \%$ versus $28 \%)$.
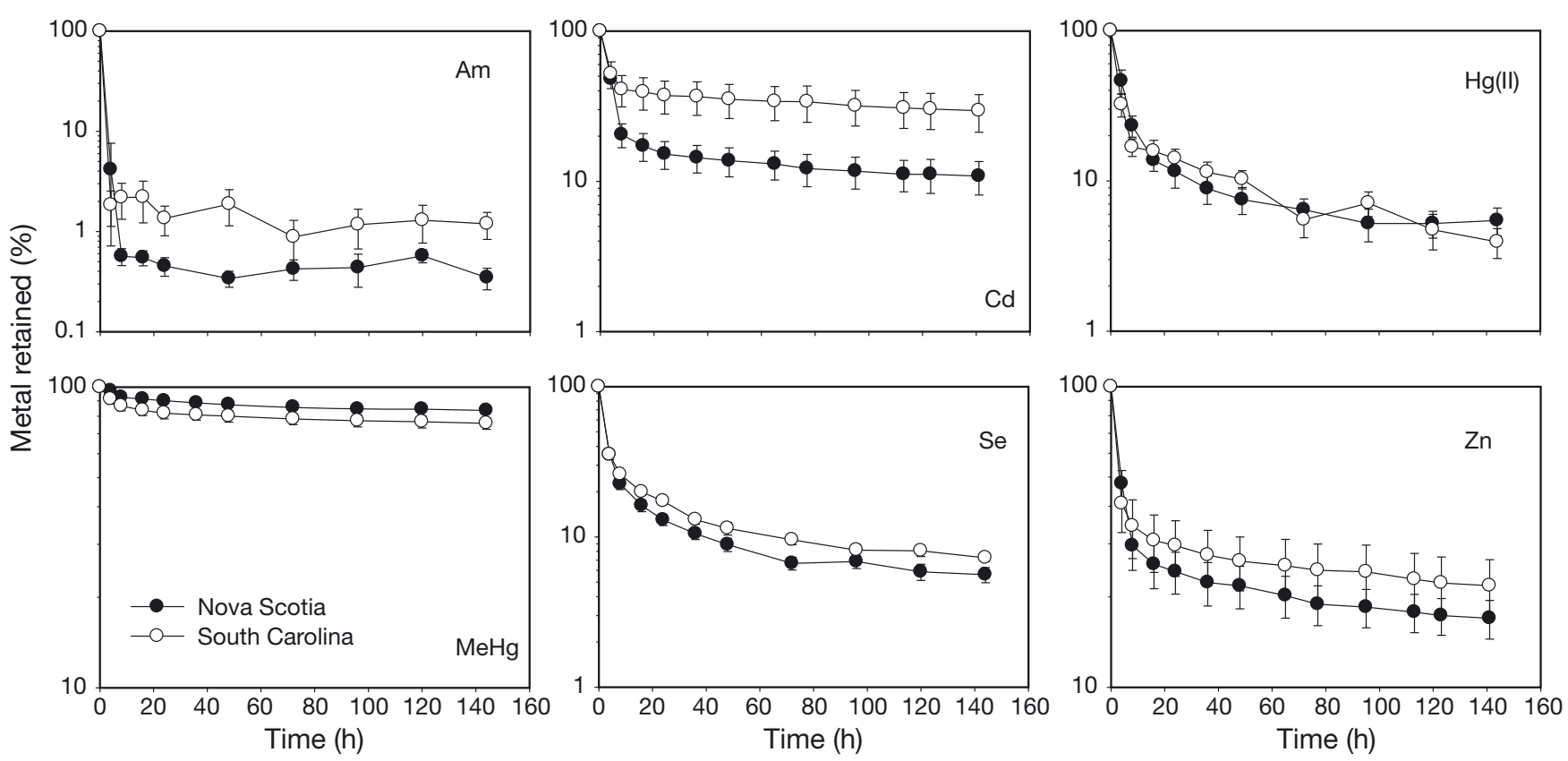

Fig. 2. Menidia menidia. Metal retention in Atlantic silversides from Nova Scotia and South Carolina after pulse feeding on brine shrimp (Artemia franciscana) nauplii ( $\mathrm{n}=5$ to 8 per population). Retention is expressed as percent of initial body burden after exposure. Values represent means $\pm 1 \mathrm{SE}$ 

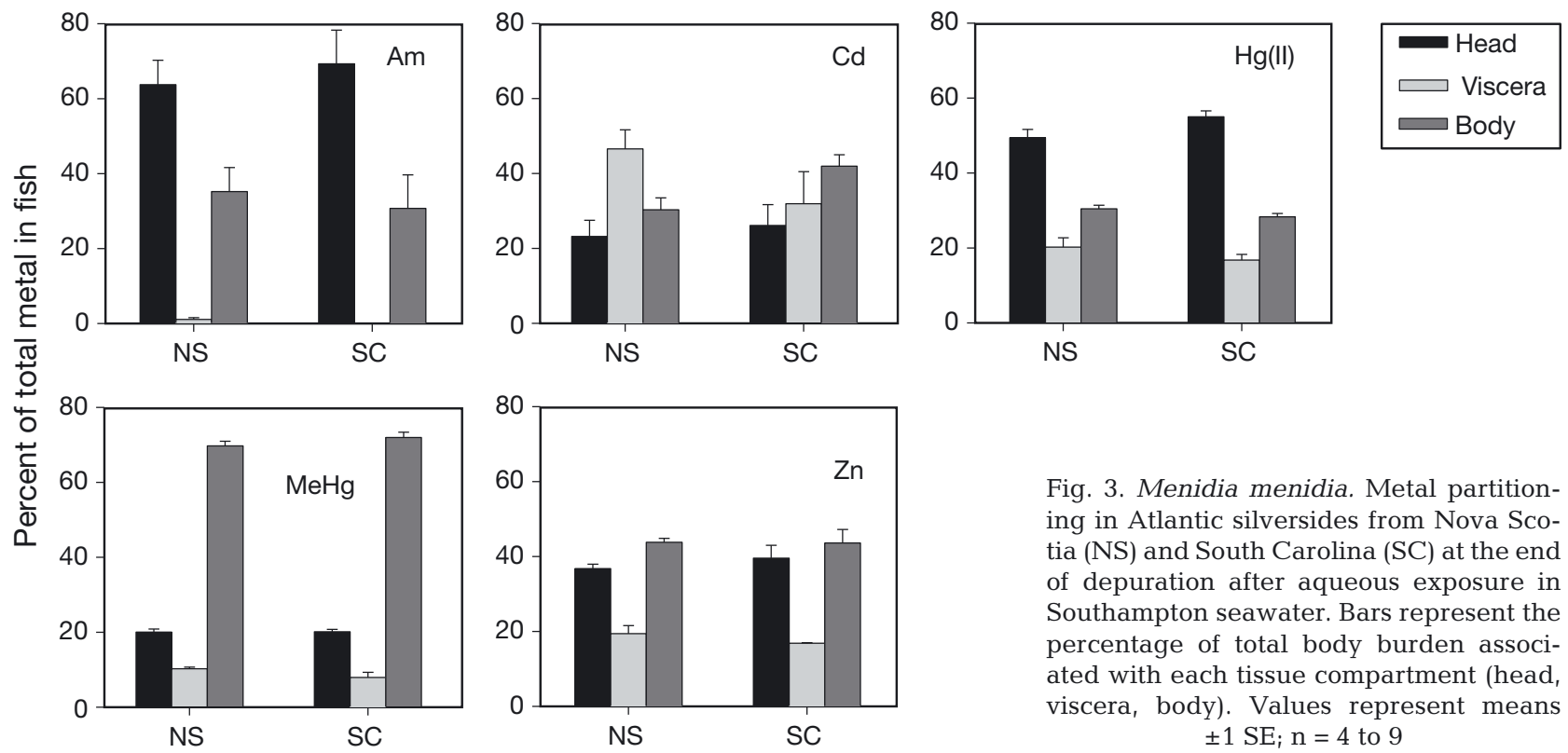

Fig. 3. Menidia menidia. Metal partitioning in Atlantic silversides from Nova Scotia (NS) and South Carolina (SC) at the end of depuration after aqueous exposure in Southampton seawater. Bars represent the percentage of total body burden associated with each tissue compartment (head, viscera, body). Values represent means $\pm 1 \mathrm{SE} ; \mathrm{n}=4$ to 9
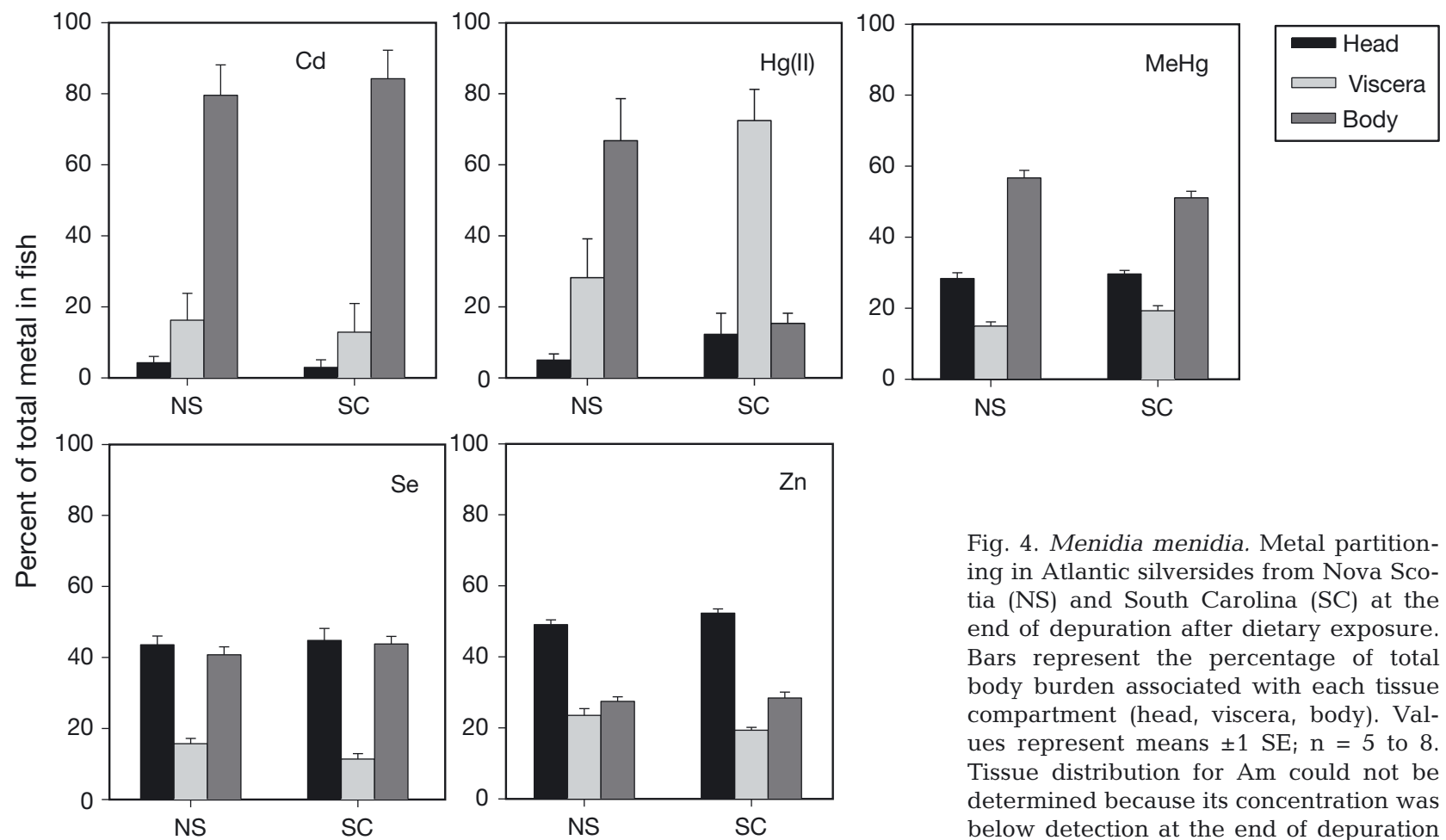

The body distribution of $\mathrm{Cd}, \mathrm{Hg}(\mathrm{II}), \mathrm{MeHg}$, and $\mathrm{Zn}$ varied with exposure route (Figs. $3 \& 4$ ). At the end of depuration after aqueous exposure, $\mathrm{Cd}$ was distributed throughout the 3 tissue compartments, whereas after dietary exposure, $\mathrm{Cd}$ was mainly associated with the body. $\mathrm{Hg}$ (II) had a higher percentage associated with the head after aqueous exposure, but after dietary exposure it was predominantly associated with the vis- cera (South Carolina population) or body (Nova Scotia population). MeHg had a higher percentage associated with the body, and lower percentages associated with the head and viscera after an aqueous exposure. Zn was predominantly associated with the head after a dietary exposure, whereas it was nearly evenly distributed between the head and body after an aqueous exposure. 
Table 3 shows the weight-normalized radioactivity concentration $\left(\mathrm{Bq} \mathrm{g}^{-1}\right)$ of each metal in tissue compartments at the end of depuration after aqueous and dietary exposures. Comparisons can be made between populations after aqueous exposure to each individual metal as all fish were exposed to the same dissolved metal concentration, whereas no comparison can be made between populations after dietary exposure to each metal as fish consumed different amounts of food. After aqueous exposure, radioactivity concentrations of $\mathrm{Cd}, \mathrm{Hg}(\mathrm{II})$, and $\mathrm{Zn}$ were highest in the viscera, and South Carolina silversides had higher tissue burdens; whereas the Am concentration was highest in the head for both populations, and Nova Scotia silversides had a higher tissue burden. For MeHg, South Carolina fish had a higher body burden in all tissue compartments, but the tissue burden was highest in the viscera for South Carolina fish, and distributed between the head and body in Nova Scotia fish. After dietary exposure, $\mathrm{Hg}(\mathrm{II}), \mathrm{MeHg}$, and Se tissue concentrations were highest in the viscera for both populations, whereas Cd was most concentrated in the body. Zn was most concentrated in the viscera in Nova Scotia fish, compared to the head in South Carolina fish.

\section{Modeling metal bioaccumulation in Menidia menidia}

The biological half-life $\left(t b_{1 / 2}\right)$ of metals in both silverside populations are shown in Table 4. For metals in which aqueous and dietary exposure routes could be compared, the $t b_{1 / 2}$ values were highest for MeHg (50 to $116 \mathrm{~d})$, followed by Am (17 to $30 \mathrm{~d}), \mathrm{Zn}$ (11 to $14 \mathrm{~d}), \mathrm{Cd}$ (9 to $13 \mathrm{~d}$ ), and lowest for $\mathrm{Hg}$ (II) (4 to $10 \mathrm{~d}$ ). The $t b_{1 / 2}$ for Se could only be calculated after a dietary exposure $(6$ to $7 \mathrm{~d}$ ). For $\mathrm{Cd}, \mathrm{Hg}(\mathrm{II})$, and $\mathrm{Zn}$ there was little differ-
Table 4. Menidia menidia. Biological half-lives $\left(t b_{1 / 2 i}\right.$ d) of metals in Nova Scotia (NS) and South Carolina (SC) populations of the Atlantic silverside after aqueous and dietary exposure.

$k_{\mathrm{e}}$ values used are in Tables $1 \& 2$. nd: not determined

\begin{tabular}{|c|c|c|c|}
\hline & Population & Aqueous $t b_{1 / 2}$ & Dietary $t b_{1 / 2}$ \\
\hline $\mathrm{Am}$ & $\begin{array}{l}\text { NS } \\
\text { SC }\end{array}$ & $\begin{array}{l}18 \\
30\end{array}$ & $\begin{array}{l}17^{\mathrm{a}} \\
17^{\mathrm{a}}\end{array}$ \\
\hline $\mathrm{Cd}$ & $\begin{array}{l}\text { NS } \\
\text { SC }\end{array}$ & $\begin{array}{c}13 \\
9\end{array}$ & $\begin{array}{c}9 \\
13\end{array}$ \\
\hline $\mathrm{Hg}(\mathrm{II})$ & $\begin{array}{l}\text { NS } \\
\text { SC }\end{array}$ & $\begin{array}{c}10 \\
9\end{array}$ & $\begin{array}{l}8 \\
4\end{array}$ \\
\hline $\mathrm{MeHg}$ & $\begin{array}{l}\text { NS } \\
\text { SC }\end{array}$ & $\begin{array}{c}116 \\
50\end{array}$ & $\begin{array}{l}63 \\
53\end{array}$ \\
\hline $\mathrm{Se}$ & $\begin{array}{l}\text { NS } \\
\text { SC }\end{array}$ & $\begin{array}{l}\text { nd } \\
\text { nd }\end{array}$ & $\begin{array}{l}6 \\
7\end{array}$ \\
\hline $\mathrm{Zn}$ & $\begin{array}{l}\text { NS } \\
\text { SC }\end{array}$ & $\begin{array}{l}11 \\
12\end{array}$ & $\begin{array}{l}12 \\
14\end{array}$ \\
\hline \multicolumn{4}{|c|}{$\begin{array}{l}\text { a We used a } k_{\text {ef }} \text { of } 0.04 \mathrm{~d}^{-1} \text {, calculated for juvenile striped } \\
\text { bass (Baines et al. 2002), due to near-complete elimination } \\
\text { of the radioisotope in our experiments }\end{array}$} \\
\hline
\end{tabular}

ence in $t b_{1 / 2}$ among populations and exposure routes. There was little difference between the $t b_{1 / 2}$ values of $\mathrm{MeHg}$ between exposure routes for the South Carolina silversides, but a large difference for Nova Scotia silversides; the $t b_{1 / 2}$ was also 2.3 times greater in the Nova Scotia population than in the South Carolina population after aqueous exposure. The $t b_{1 / 2}$ of Am was 1.7 times higher in South Carolina silversides after an aqueous exposure. We could not determine the $k_{\text {ef }}$ after dietary exposure due to near complete elimination of the radioisotope, so for our model we applied a value of $0.04 \mathrm{~d}^{-1}$ calculated for juvenile striped bass (Baines et al. 2002). Assuming it takes $7 t b_{1 / 2}$ for all radioisotopes to be eliminated from an organism, the residence time of each metal can be calculated. After

Table 3. Menidia menidia. Radioactivity concentration ( $\mathrm{Bq}^{-1}$ ) of metals in fish tissues (head, viscera, and body) after aqueous and dietary exposure. NS = Nova Scotia, $\mathrm{SC}=$ South Carolina. Values represent means $\pm 1 \mathrm{SE} ; \mathrm{nd}$ : not determined. $\mathrm{n}=4$ to 9 per population for aqueous exposure and 5 to 8 per population for dietary exposure

\begin{tabular}{|c|c|c|c|c|c|c|c|}
\hline & \multirow{2}{*}{ Population } & \multirow{2}{*}{\multicolumn{2}{|c|}{$\begin{array}{c}\text { Aqueous exposure } \\
\text { Viscera }\end{array}$}} & \multirow[b]{2}{*}{ Body } & \multirow[b]{2}{*}{ Head } & \multirow{2}{*}{$\begin{array}{l}\text { Dietary exposure } \\
\text { Viscera }\end{array}$} & \multirow[b]{2}{*}{ Body } \\
\hline & & & & & & & \\
\hline $\mathrm{Am}$ & $\begin{array}{l}\text { NS } \\
\text { SC }\end{array}$ & $\begin{array}{l}144 \pm 12 \\
114 \pm 22\end{array}$ & $\begin{array}{c}17 \pm 8 \\
0 \pm 0\end{array}$ & $\begin{array}{c}37 \pm 10 \\
23 \pm 7\end{array}$ & $\begin{array}{l}\text { nd } \\
\text { nd }\end{array}$ & $\begin{array}{l}\text { nd } \\
\text { nd }\end{array}$ & $\begin{array}{l}\text { nd } \\
\text { nd }\end{array}$ \\
\hline $\mathrm{Cd}$ & $\begin{array}{l}\mathrm{NS} \\
\mathrm{SC}\end{array}$ & $\begin{array}{c}33 \pm 7 \\
75 \pm 47\end{array}$ & $\begin{array}{c}128 \pm 24 \\
342 \pm 211\end{array}$ & $\begin{array}{l}12 \pm 1 \\
22 \pm 6\end{array}$ & $\begin{array}{c}116 \pm 39 \\
303 \pm 124\end{array}$ & $\begin{array}{c}1372 \pm 601 \\
9842 \pm 6856\end{array}$ & $\begin{aligned} 2537 & \pm 640 \\
14338 & \pm 3812\end{aligned}$ \\
\hline $\operatorname{Hg}(\mathrm{II})$ & $\begin{array}{l}\mathrm{NS} \\
\mathrm{SC}\end{array}$ & $\begin{array}{l}113 \pm 8 \\
113 \pm 9\end{array}$ & $\begin{array}{l}144 \pm 16 \\
174 \pm 25\end{array}$ & $\begin{array}{l}26 \pm 3 \\
22 \pm 1\end{array}$ & $\begin{array}{l}8 \pm 3 \\
8 \pm 3\end{array}$ & $\begin{array}{c}97 \pm 48 \\
146 \pm 80\end{array}$ & $\begin{aligned} 89 & \pm 17 \\
8 & \pm 1\end{aligned}$ \\
\hline $\mathrm{MeHg}$ & $\begin{array}{l}\text { NS } \\
\text { SC }\end{array}$ & $\begin{array}{c}948 \pm 173 \\
2803 \pm 280\end{array}$ & $\begin{array}{c}817 \pm 152 \\
4733 \pm 1217\end{array}$ & $\begin{array}{c}941 \pm 204 \\
3318 \pm 306\end{array}$ & $\begin{array}{l}3184 \pm 920 \\
4173 \pm 637\end{array}$ & $\begin{array}{l}6169 \pm 1701 \\
9728 \pm 4217\end{array}$ & $\begin{array}{c}4799 \pm 1528 \\
4982 \pm 829\end{array}$ \\
\hline $\mathrm{Se}$ & $\begin{array}{l}\text { NS } \\
\text { SC }\end{array}$ & $\begin{array}{l}\text { nd } \\
\text { nd }\end{array}$ & $\begin{array}{l}\text { nd } \\
\text { nd }\end{array}$ & $\begin{array}{l}\text { nd } \\
\text { nd }\end{array}$ & $\begin{array}{c}936 \pm 78 \\
1030 \pm 75\end{array}$ & $\begin{array}{l}2192 \pm 478 \\
1470 \pm 336\end{array}$ & $\begin{array}{l}474 \pm 51 \\
554 \pm 52\end{array}$ \\
\hline $\mathrm{Zn}$ & $\begin{array}{l}\mathrm{NS} \\
\mathrm{SC}\end{array}$ & $\begin{array}{l}219 \pm 26 \\
612 \pm 58\end{array}$ & $\begin{array}{c}219 \pm 30 \\
1718 \pm 1201\end{array}$ & $\begin{array}{c}73 \pm 4 \\
189 \pm 35\end{array}$ & $\begin{array}{c}4303 \pm 451 \\
8255 \pm 1665\end{array}$ & $\begin{array}{l}5112 \pm 1266 \\
6986 \pm 1189\end{array}$ & $\begin{array}{l}1892 \pm 291 \\
3006 \pm 394\end{array}$ \\
\hline
\end{tabular}


aqueous exposure, the calculated residence times (d) of each metal in Nova Scotia and South Carolina silversides, respectively, were as follows: Am $(126,210), \mathrm{Cd}$ (91, 63), $\mathrm{Hg}(\mathrm{II})(70,63), \mathrm{MeHg}(812,350)$, and $\mathrm{Zn}(77$, 84). After dietary exposure, they were: $\operatorname{Am}(153,153)$, Cd $(63,91), \operatorname{Hg}(\mathrm{II})(56,28), \mathrm{MeHg}(441,371)$, Se $(42$, 49), and $\mathrm{Zn}(84,98)$.

Model-predicted body burdens of metals in both silverside populations at steady-state $\left(C_{\mathrm{ss}}\right)$ were highest for $\mathrm{Zn}\left(202\right.$ and $246 \mu \mathrm{g} \mathrm{g}^{-1}$ for Nova Scotia and South Carolina silversides, respectively), followed by $\mathrm{Cd}$ (1.7 and $\left.4.9 \mu \mathrm{g} \mathrm{g}^{-1}\right), \mathrm{MeHg}\left(1.3\right.$ and $\left.1.4 \mu \mathrm{g} \mathrm{g}^{-1}\right)$, Se $(0.45$ and $\left.0.49 \mu \mathrm{g} \mathrm{g}^{-1}\right), \mathrm{Hg}$ (II) (18 and $15 \mathrm{ng} \mathrm{g}^{-1}$ ), and lowest for Am $\left(3.6 \times 10^{-10}\right.$ and $\left.1.4 \times 10^{-9} \mathrm{ng} \mathrm{g}^{-1}\right)$ (Table 5). The calculated body burden was $4,2.9,1.1,1.1$, and 1.2 times higher for $\mathrm{Am}, \mathrm{Cd}, \mathrm{MeHg}, \mathrm{Se}$, and $\mathrm{Zn}$, respectively, in South Carolina silversides, and 1.2 times higher for $\mathrm{Hg}$ (II) in Nova Scotia silversides. Diet was the dominant source for $\mathrm{Cd}, \mathrm{Hg}(\mathrm{II}), \mathrm{MeHg}$, and $\mathrm{Zn}$, accounting for $>96 \%$ of accumulated metal. Diet is assumed to account for $100 \%$ of accumulated metal for Se (Stewart et al. 2010). Am was the only metal for which the aqueous phase accounted for a significant percentage of accumulated metal (38.3 to 61.1\%) (Table 5). TTFs were $<1$ for Am, Hg(II), and Se, indicating that these metals would not be expected to biomagnify in juvenile Menidia menidia, whereas TTFs were $\sim 1$ for Zn and >>1 for MeHg in both populations, and $>1$ for $\mathrm{Cd}$ in South Carolina silversides (Table 5), indicating that biomagnification is likeliest for $\mathrm{MeHg}$ at this trophic step.

Table 5. Menidia menidia. Model-predicted metal body burdens at steady-state $\left(C_{\mathrm{ss}}\right)$, percent of body burden attributed to dietary exposure, and trophic transfer factors (TTFs) for Nova Scotia (NS) and South Carolina (SC) Atlantic silverside populations. Kinetic parameters used are in Tables $1 \& 2$. $C_{\text {ss }}$ units are $\mu \mathrm{g} \mathrm{g}^{-1}(\mathrm{Cd}, \mathrm{MeHg}, \mathrm{Se}, \mathrm{Zn})$ and $\mathrm{ng} \mathrm{g}^{-1}$ (Am, Hg(II))

\begin{tabular}{|c|c|c|c|c|}
\hline \multicolumn{2}{|c|}{ Population } & $C_{\mathrm{ss}}$ & $\%$ attributed to diet & TTF \\
\hline \multirow[t]{2}{*}{$\mathrm{Am}$} & NS & $3.6 \times 10^{-10}$ & 38.3 & $0.02^{\circ}$ \\
\hline & $\mathrm{SC}$ & $1.4 \times 10^{-9}$ & 61.1 & $0.11^{\mathrm{c}}$ \\
\hline \multirow[t]{2}{*}{$\mathrm{Cd}$} & NS & 1.7 & $>99.9$ & 0.67 \\
\hline & $\mathrm{SC}$ & 4.9 & $>99.9$ & 1.95 \\
\hline \multirow[t]{2}{*}{$\operatorname{Hg}(\mathrm{II})$} & NS & 18 & 97.9 & 0.32 \\
\hline & $\mathrm{SC}$ & 15 & 96.1 & 0.26 \\
\hline \multirow[t]{2}{*}{$\mathrm{MeHg}$} & NS & 1.3 & $>99.9$ & 7.6 \\
\hline & $\mathrm{SC}$ & 1.4 & $>99.7$ & 8.7 \\
\hline \multirow[t]{2}{*}{$\mathrm{Se}$} & NS & 0.45 & 100 & 0.35 \\
\hline & $\mathrm{SC}$ & 0.49 & 100 & 0.38 \\
\hline \multirow[t]{2}{*}{$\mathrm{Zn}$} & NS & 202 & $>99.9$ & 1.2 \\
\hline & $\mathrm{SC}$ & 246 & $>99.8$ & 1.5 \\
\hline \multicolumn{5}{|c|}{$\begin{array}{l}\text { a We used a } k_{\text {ef }} \text { of } 0.04 \mathrm{~d}^{-1} \text {, calculated for juvenile striped } \\
\text { bass (Baines et al. 2002), due to near-complete elimination } \\
\text { of the radioisotope in our experiments }\end{array}$} \\
\hline
\end{tabular}

\section{DISCUSSION}

\section{Aqueous uptake of metals}

Our results show that the rate of metal uptake from the dissolved phase varied by metal. For all metals and both populations, CFs were $>1$, indicating fish are more enriched in metal than the surrounding water. CFs and $k_{\mathrm{u}} \mathrm{s}$ were higher in fish from South Carolina than from Nova Scotia, indicating that body size may influence the rate of metal uptake, as observed by Zhang \& Wang (2007). We attribute this difference to the larger surface area to volume ratio in South Carolina silversides, which were smaller. Differences in respiration rate between the 2 populations could also account for some of the difference, but respiration rates were not measured during this study.

The MeHg $k_{\mathrm{u}}$ values obtained in this study (1155 and $4375 \mathrm{ml} \mathrm{g}^{-1} \mathrm{~d}^{-1}$ ) are similar to those found for the marine sweetlips Plectorhinchus gibbosus $(4515 \mathrm{ml}$ $\mathrm{g}^{-1} \mathrm{~d}^{-1}$, Wang \& Wong 2003) and the freshwater redear sunfish Lepomis microlophus $\left(1280 \mathrm{ml} \mathrm{g}^{-1} \mathrm{~d}^{-1}\right.$, Pickhardt et al. 2006), but higher than those determined for the freshwater mosquitofish Gambusia affinis (185 to $338 \mathrm{ml} \mathrm{g}^{-1} \mathrm{~d}^{-1}$, Pickhardt et al. 2006). Our Hg(II) $k_{\mathrm{u}}$ values (15 and $17 \mathrm{ml} \mathrm{g}^{-1} \mathrm{~d}^{-1}$ ) are slightly lower than those observed in freshwater fish (38 to $78 \mathrm{ml} \mathrm{g}^{-1} \mathrm{~d}^{-1}$, Pickhardt et al. 2006), and 10-fold lower than that observed in marine fish (195 $\mathrm{ml} \mathrm{g}^{-1} \mathrm{~d}^{-1}$, Wang \& Wong 2003). Our values could be lower than observed in other studies due to $\mathrm{Hg}(\mathrm{II})$ binding to dissolved organic matter. The higher MeHg $k_{\mathrm{u}}$ compared to $\mathrm{Hg}$ (II) $k_{\mathrm{u}}$ (77 times higher in Nova Scotia silversides, and 257 times higher in South Carolina silversides) is consistent with previous reports for other fish (Wang \& Wong 2003, Pickhardt et al. 2006), indicating that $\mathrm{Hg}(\mathrm{II})$ is absorbed less efficiently than $\mathrm{MeHg}$. $\mathrm{Hg}$ (II) uptake is considered to be a more passive process due to Hg forming uncharged, inorganic complexes in water (Mason et al. 1996), whereas MeHg uptake across the gills is thought to be an energy-mediated process (Andres et al. 2002).

Our uptake rate constants for Am (11 and $13 \mathrm{ml}$ $\mathrm{g}^{-1} \mathrm{~d}^{-1}$ ) are consistent with observations in juvenile sea bream Sparus auratus $\left(10 \mathrm{ml} \mathrm{g}^{-1} \mathrm{~d}^{-1}\right.$, Mathews et al. 2008), and Cd uptake (0.8 and $1.3 \mathrm{ml} \mathrm{g}^{-1} \mathrm{~d}^{-1}$ ) is similar to that observed in other marine species, including sea bream (5 $\left.\mathrm{ml} \mathrm{g}^{-1} \mathrm{~d}^{-1}\right)$ and mangrove snapper Lutjanus argentimaculatus (5.1 $\mathrm{ml} \mathrm{g}^{-1} \mathrm{~d}^{-1}, \mathrm{Xu} \&$ Wang 2002). Am is highly particle-reactive (Fisher \& Reinfelder 1995), accounting for its higher uptake rate than the other metals examined (except $\mathrm{Hg}$ (II) and $\mathrm{MeHg}$ ). Cd uptake rates here are lower than what would be expected for freshwater fish, due to complexation of $\mathrm{Cd}^{2+}$ with $\mathrm{Cl}^{-}$in saline water resulting in reduced bioavailability. A prior study using the tidewater silverside Menidia 
beryllina showed that fish accumulate less Cd via the dissolved phase at higher salinities (Jackson et al. 2003). Our Zn uptake rates (1.9 and $5.0 \mathrm{ml} \mathrm{g}^{-1} \mathrm{~d}^{-1}$ ) are similar to that noted in the sea bream $\left(4 \mathrm{ml} \mathrm{g}^{-1} \mathrm{~d}^{-1}\right.$, Mathews et al. 2008), but lower than that observed in the mangrove snapper (10 $\mathrm{ml} \mathrm{g}^{-1} \mathrm{~d}^{-1}$, Xu \& Wang 2002).

\section{Assimilation efficiencies}

The wide range of AEs $0.3 \%$ for Am to $89 \%$ for $\mathrm{MeHg}$ ) observed in our study indicates that they are highly variable among metals. The AE ranking we noted is consistent with the observations of Reinfelder \& Fisher (1991) in copepods, who found that AEs in these animals are related to the percentage of metal associated with the cytoplasm in phytoplankton food. Apart from $\mathrm{Cd}$, no pronounced difference was noted in metal AEs between the 2 populations.

Our MeHg AE values (89\% for Nova Scotia, 82\% for South Carolina) are slightly lower, but comparable to other literature values for freshwater, estuarine, and marine fish fed zooplankton prey (89 to 95\%; Wang \& Wong 2003, Pickhardt et al. 2006, Mathews \& Fisher 2008a). For both populations, MeHg assimilation greatly exceeded $\mathrm{Hg}$ (II) assimilation, being 11-fold higher in Nova Scotia silversides, and 5.5-fold higher in South Carolina silversides. This difference in assimilation could be a result of fish gut chemistry, with $\mathrm{MeHg}$ being more readily desorbed from ingested food, and passively and actively transported across the intestinal wall (Leaner \& Mason 2002). Furthermore, it has been noted that $\mathrm{MeHg}$ AEs are higher than Hg(II) AEs in fish, because a larger percentage of $\mathrm{MeHg}$ in zooplankton is associated with the soft tissue (Lawson \& Mason 1998). This higher assimilation of MeHg in zooplankton is attributed to the accumulation of $\mathrm{MeHg}$ in algal cytoplasm, while inorganic Hg remains largely bound to cell surfaces (Mason et al. 1995). The calculated $\mathrm{Hg}(\mathrm{II})$ AEs in this study (8\% for Nova Scotia, 15\% for South Carolina) are similar to those observed in other freshwater and marine fish (8.5 to $27 \%$; Wang \& Wong 2003, Pickhardt et al. 2006), but much lower than those observed in the freshwater mosquitofish (42 to 51\%, Pickhardt et al. 2006). However, those authors noted that after $2 \mathrm{~d}$ depuration, some mosquitofish were still producing radioactive feces, suggesting a longer gut passage time than for the Atlantic silverside $(<8 \mathrm{~h})$. This allows more time to solubilize the metal in the gut, resulting in a higher AE.

$\mathrm{Cd}$ assimilation showed the greatest variation between the 2 silverside populations. The AEs observed (15\% for Nova Scotia, 39\% for South Carolina) are within the range noted for other estuarine and marine fish fed zooplankton prey (21 to $28 \%$; Baines et al. 2002,
Mathews \& Fisher 2008b). However, our values were higher than those observed for killifish Fundulus heteroclitus (7\%, Mathews \& Fisher 2008a), grunt Terapon jarbua (6.3\%, Zhang \& Wang 2006), and mangrove snapper (9.8\%, Xu \& Wang 2002) fed zooplankton prey. These differences in AEs could be due to the variation in Cd bioavailability among different zooplankton prey items. Ni et al. (2000) noted that when the mudskipper Periophthalmus cantonensis and glassy Ambassis urotaenia were fed brine shrimp nauplii the AEs resembled our values (26 to $32 \%$ ), but when the fish were fed copepods, the AEs decreased to 10 to $14 \%$. This was also noted in another study in which uniformly radiolabeled copepods were fed to silversides (Menidia menidia, $M$. beryllina), resulting in an AE of $3 \%$ (Reinfelder \& Fisher 1994a). This pronounced difference in $\mathrm{Cd}$ AE between the 2 populations cannot be attributed to differences in feeding behavior: Cd was double-labeled with Zn, and there was no significant difference in $\mathrm{Zn}$ AEs between silverside populations.

Am had the lowest AEs of all the investigated metals. Our Am AE values (0.3 to $1.9 \%$ ) are lower than other values noted in fish fed zooplankton prey (4 to $6 \%$; Baines et al. 2002, Mathews \& Fisher 2008b). Nearly all Am had been lost from both silverside populations within the first $8 \mathrm{~h}$ of depuration, and if the fish were radioassayed more frequently during this time, Am could be used as a tracer to calculate an accurate gut passage time, as noted for copepods (Fisher \& Reinfelder 1991). Low Am AEs in fish can be attributed to a low Am AE in zooplankton, which in turn is attributed to the low percentage of Am associated with cytoplasm in phytoplankton (Reinfelder \& Fisher 1991, 1994b). Also, Am is not known to share cellular uptake channels with other elements, unlike $\mathrm{Cd}$, another biologically non-essential element which can be taken up through $\mathrm{Ca}$ and $\mathrm{Zn}$ uptake channels (Brzóska \& Moniuszko-Jakoniuk 2001, Franklin et al. 2005).

Zn and Se are both biologically essential, regulated metals found in proteins, and used as cofactors in enzymes (Eisler 1985, 1993). Both metals showed little variation in assimilation between the 2 populations. The Zn AEs reported in this study (24\% in Nova Scotia, $29 \%$ in South Carolina) are comparable to those obtained for grunt (23\%), striped bass (23 to $40 \%$ ), and mudskipper $(21 \%)$ fed zooplankton prey ( $\mathrm{Ni}$ et al. 2000, Baines et al. 2002, Zhang \& Wang 2006). Our values are higher than those reported for glassy (5 to $17 \%$, Ni et al. 2000), mangrove snapper (14.5\%, Xu \& Wang 2002), sea bream (14\%, Mathews \& Fisher 2008b), and silversides (6\%, Reinfelder \& Fisher 1994a). This difference could be attributed to the different partitioning of $\mathrm{Zn}$ between the exoskeleton and soft body tissue of the zooplankton prey. Our Se AEs (10\% for Nova Scotia, $13 \%$ for South Carolina) are lower than 
AEs calculated for other fish fed zooplankton prey (29 to $77 \%$; Reinfelder \& Fisher 1994a, Baines et al. 2002, Xu \& Wang 2002, Zhang \& Wang 2006, Mathews \& Fisher 2008b), for reasons not apparent.

For Am, Cd, and $\mathrm{Hg}(\mathrm{II})$, South Carolina fish assimilated more metal than Nova Scotia fish, but the difference was only statistically significant for $\mathrm{Am}$ and $\mathrm{Cd}$ ( $t$-test, $\mathrm{p}<0.05$ ), and Cd was the only metal where a pronounced difference was noted. Although Am showed the largest difference between the 2 populations, nearly all of the radioisotope was lost, so radioactive counts in the fish were not high above background level, resulting in a large propagated counting error which could influence our values. The higher metal AE in South Carolina fish could possibly be explained by an estimated 1.6 times lower ingestion rate. Xu \& Wang (2002) noted that as the ingestion rate of the mangrove snapper increased from 0.05 to $0.57 \mathrm{~g} \mathrm{~g}^{-1} \mathrm{~d}^{-1}$ the $\mathrm{AE}$ of $\mathrm{Cd}$, Se, and $\mathrm{Zn}$ decreased substantially (from 24 to $7 \%, 69$ to $54 \%$, and 43 to $17 \%$ respectively), indicating that metal assimilation from the diet is dependent on ingestion rate, a parameter that is commonly ignored in dietary studies. This relationship suggests that a higher ingestion rate allows less time for food-bound metal to have contact with the gut, resulting in less metal becoming solubilized and bioavailable. We did not measure gut passage time in our study, but observed that, for both populations, the most radioactive feces were produced within the first 4 to $8 \mathrm{~h}$ after feeding. However, Xu \& Wang (2002) noted that at high ingestion rates (as in both our silverside populations: 0.37 and $0.58 \mathrm{~g} \mathrm{~g}^{-1} \mathrm{~d}^{-1}$ ) there is no difference in $\mathrm{Cd}$, Se, and Zn AEs, indicating that ingestion rate only has an influence on AE when food is in low supply. This is consistent with our findings for Se and $\mathrm{Zn}$, but not for $\mathrm{Cd}$.

Nova Scotia silversides have a 1.8 to 2.2 times higher growth efficiency (defined as percentage of consumed energy used to create biomass), as well as a higher ingestion rate than South Carolina silversides (Present $\&$ Conover 1992). Nova Scotia silversides also accumulate lipids at a faster rate than South Carolina fish (Schultz \& Conover 1997). MeHg was the only metal which Nova Scotia fish assimilated more than South Carolina fish. Although the difference in AE between the 2 populations was $7 \%$, it was found to be statistically significant ( $\mathrm{p} 0.05)$, and the increased lipid content may enable Nova Scotia fish to accumulate more $\mathrm{MeHg}$ from their diet, resulting in a higher AE.

\section{Efflux rates after aqueous and dietary exposure}

The similar efflux rates between the 2 population and exposure routes (except for South Carolina silversides after $\mathrm{Hg}(\mathrm{II})$ exposure where the efflux rate was 2.6 times higher after a dietary exposure) could be attributed to a similar routine metabolic rate at the experimental temperature we used. Billerbeck et al. (2000) found that the metabolic rate (measured as $\mathrm{O}_{2}$ consumption) was comparable for the 2 populations at $17^{\circ} \mathrm{C}$ and $22^{\circ} \mathrm{C}$ (our experiments were conducted at $21^{\circ} \mathrm{C}$ ), but was significantly higher in Nova Scotia silversides at $28^{\circ} \mathrm{C}$. Therefore, the physiological turnover of metal within tissues would be expected to be similar, consistent with the comparable efflux rates for metals in both populations. The similarity in metabolic rate could also explain why the uptake rates of Am and $\mathrm{Hg}$ (II) were similar in the 2 populations. The high efflux rates for all metals except $\mathrm{MeHg}$ after dietary exposure indicate that digestive processes aid in the rapid removal of metal. This was particularly evident for $\mathrm{Hg}$ (II) in South Carolina silversides, where it was primarily localized in the gut, and had the highest efflux rate of $19 \% \mathrm{~d}^{-1}$. The high efflux rates after aqueous exposure indicate that different pools of metals are rapidly turned over in the fish and excreted, and unlike in dietary exposure, egestion does not play a role.

Our $k_{\mathrm{ew}}$ values for $\mathrm{Am}, \mathrm{Cd}, \mathrm{Hg}(\mathrm{II}), \mathrm{MeHg}$, and $\mathrm{Zn}$ are similar to those determined in other studies (Wang \& Wong 2003, Pickhardt et al. 2006, Mathews et al. 2008). However, our values for $\mathrm{Am}, \mathrm{Cd}$, and $\mathrm{Zn}$ are higher than those for turbot (Jeffree et al. 2006). The latter study used larger, more mature fish with lower metabolic rates than the juveniles we used. Our $\mathrm{Cd}$ and $\mathrm{Zn}$ efflux rates were higher than those observed by $\mathrm{Xu} \&$ Wang (2002). They used fish of a similar size to ours, but silversides may have a higher metabolic rate than mangrove snappers due to rapid growth, which would account for this difference. Our $\mathrm{Hg}$ (II) $k_{\text {ew }}$ values are at least 1.7 times higher than those noted for freshwater fish (Pickhardt et al. 2006). This difference could be due to osmoregulatory differences between freshwater and marine fish: marine fish actively drink water to replace what is lost from tissues and through salt removal across gills, and if $\mathrm{Hg}(\mathrm{II})$ is excreted unselectively through the same ion-transport channels used for salt removal, the efflux rate will be higher.

Our $k_{\text {ef }}$ values for MeHg are consistent with those obtained in other studies of fish fed zooplankton prey (Wang \& Wong 2003, Pickhardt et al. 2006, Mathews \& Fisher 2008a). Our $k_{\text {ef }}$ values for $\mathrm{Cd}$, Se, and $\mathrm{Zn}$ are also within the ranges noted in other studies where fish were fed zooplankton prey (Xu \& Wang 2002, Mathews $\&$ Fisher 2008a,b), but unlike for $\mathrm{MeHg}$, there is greater variability in these efflux rates among studies. Our $\mathrm{Hg}(\mathrm{II}) k_{\text {ef }}$ values were higher than those determined for freshwater fish (Pickhardt et al. 2006), but the Nova Scotia silverside $k_{\text {ef }}$ was consistent with that of marine sweetlips (Wang \& Wong 2003), whereas the South Carolina silverside $k_{\text {ef }}$ was 2.0 times higher. At the end of $6 \mathrm{~d}$ depuration, $\mathrm{Hg}$ (II) was primarily associated with 
the gut in South Carolina silversides, accounting for the high $k_{\text {ef }}$ suggesting that metal loss should be monitored for a longer period of time. Wang \& Wong (2003) noted that during the first $7 \mathrm{~d}$ of metal loss in fish, $\mathrm{Hg}$ (II) efflux rates were higher after both dietary and aqueous exposures, and decreased significantly between 9 and $28 \mathrm{~d}$ of metal loss ( $k_{\text {ef }}$ decreased from 0.096 to $0.055 \mathrm{~d}^{-1}$, $k_{\text {ew }}$ decreased from 0.072 to $0.029 \mathrm{~d}^{-1}$ ). Our Cd and $\mathrm{Zn}$ efflux rates were higher than those noted for larger, more mature sea bream and turbot fed fish prey (Mathews et al. 2008), suggesting that size influences the loss of assimilated metal. This is consistent with the findings of Baines et al. (2002), who found lower efflux rates of assimilated $\mathrm{Cd}$ and $\mathrm{Zn}$ in $88 \mathrm{~d}$ old striped bass $\left(0.03 \mathrm{~d}^{-1}\right.$ for both metals $)$ than in $43 \mathrm{~d}$ old fish $\left(0.07 \mathrm{~d}^{-1}\right.$ $\left.\mathrm{Cd}, 0.013 \mathrm{~d}^{-1} \mathrm{Zn}\right)$, consistent with the inverse relationship of metabolic rate and age.

\section{Distribution of metals in fish tissue}

Tissue partitioning varied by metal and exposure route. The gills are considered to be the primary uptake site for metals during an aqueous exposure for most metals, and the digestive tract after a dietary exposure. Except for Hg(II) after dietary exposure, and $\mathrm{Cd}$ after aqueous exposure, the tissue partitioning of each metal did not vary between the 2 populations after either aqueous or dietary exposure, indicating that both populations physiologically processed metal in the same way. After aqueous exposure, Am was mainly associated with the head (64 to 69\%), consistent with what has been observed in other studies (Jeffree et al. 2006, Mathews et al. 2008). Am is a Class A metal (Nieboer \& Richardson 1980), with a strong binding preference to the mineral phase within organisms. The head may have had the highest percentage because it is predominantly bone. Tissue partitioning after dietary exposure could not be determined due to near complete elimination of the radioisotope. After dietary exposure, Se crossed over the gut lining and was transported around the body, consistent with the findings of Baines et al. (2002) and Xu \& Wang (2002). Zn tissue partitioning was split mainly between the head and body after an aqueous exposure, and primarily associated with the head after a dietary exposure. Our tissue distribution data is consistent with other studies looking at either aqueous or dietary uptake of Zn (Baines et al. 2002, Mathews et al. 2008). Zn is a borderline metal (Nieboer \& Richardson 1980) with some association for both the mineral and protein phase, and therefore could be expected to bind to both bone in the head region and protein within body tissue.

Other studies describing $\mathrm{Cd}$ behavior in fish after dietary exposure indicate that tissue distribution varies by species. Both silverside populations used in our study had the highest percentage of Cd associated with the body ( 80 to $84 \%$ ), consistent with observations of striped bass (Baines et al. 2002). Other studies have shown that $\mathrm{Cd}$ remains associated with the gut $(\mathrm{Xu} \&$ Wang 2002, Mathews \& Fisher 2008a). Why some fish are better protected from Cd uptake across the intestine is not fully understood. Studies using rainbow trout Oncorhynchus mykiss have shown that $\mathrm{Cd}$ shares the same uptake pathway as $\mathrm{Ca}^{2+}$ in the gills and intestinal tract, and a diet enriched in $\mathrm{Ca}^{2+}$ can inhibit Cd uptake at these exposure sites by downregulating the $\mathrm{Ca}^{2+}$ uptake pathway in the gills and intestine (Franklin et al. 2005, Wood et al. 2006). However, we did not measure $\mathrm{Ca}^{2+}$ levels in our prey item to conclude whether this could have an influence in our study. Alternatively, due to their high growth rate, silversides could rapidly assimilate $\mathrm{Ca}^{2+}$ to form their skeleton, allowing $\mathrm{Cd}$ to be taken up across the gut lining. However, tissue concentrations of Cd were highest in the body, followed by the viscera. The high concentration of $\mathrm{Cd}$ in the viscera combined with the high efflux rate indicates that some of the assimilated $\mathrm{Cd}$ is detoxified and excreted by the silversides after dietary exposure. After aqueous exposure, the highest percentage of Cd was associated with the viscera in Nova Scotia silversides, and the body in South Carolina silversides, but the highest Cd concentration was in the viscera for both populations. Other studies have also noted a high percentage of Cd associated with the viscera in marine fish (Jeffree et al. 2006, Mathews et al. 2008), but this percentage decreases throughout depuration indicating a redistribution of $\mathrm{Cd}$ over time. Marine fish actively drink seawater to osmoregulate, and a study has shown that even though aqueous $\mathrm{Cd}$ accumulation decreases with an increase in salinity, the percentage body burden of Cd associated with the viscera increases with salinity, suggesting drinking is an uptake mechanism for $\mathrm{Cd}$ in marine fish (authors' unpubl. data). The higher percentage of $\mathrm{Cd}$ associated with the viscera in Nova Scotia silversides could be due to a higher drinking rate, but this was not measured in our study.

Our results show that the 2 species of mercury we examined behaved very differently. At the end of depuration after aqueous exposure, 49 to $55 \%$ of $\mathrm{Hg}$ (II) remained associated with the head, consistent with findings in mosquitofish and redear sunfish (Pickhardt et al. 2006), whereas 70 to $72 \%$ of MeHg was associated with the body, which is higher than noted previously ( 55\%, Pickhardt et al. 2006). After dietary exposure, 51 to $57 \%$ of MeHg body burden was associated with the body, consistent with that found in killifish (58\%, Mathews \& Fisher 2008a) and redear sunfish (55\%, Pickhardt et al. 2006). MeHg has been shown to solubilize more readily than $\mathrm{Hg}$ (II) during digestion 
and be transported across the intestine wall through an amino acid transport pathway, where it is redistributed around the body via the blood (Leaner \& Mason 2002, 2004) and bound to protein due to its strong affinity for sulfur. After dietary exposure, a greater percentage of $\mathrm{Hg}$ (II) was associated with the viscera in South Carolina silversides, whereas Nova Scotia silversides had a higher percentage associated with the body; reasons for this difference are not apparent. Pickhardt et al. (2006) also noted a difference in the percentage of $\mathrm{Hg}$ (II) associated with the viscera between different freshwater fish species. The long retention time of $\mathrm{Hg}$ (II) in the gut, as noted in the South Carolina silverside population and other fish studies (Pickhardt et al. 2006), may allow some Hg(II) to become methylated by gut bacteria as seen in freshwater piscivorous fish (Rudd et al. 1980). This was not observed in our study, and the high South Carolina silverside $\mathrm{Hg}(\mathrm{II}) k_{\mathrm{ef}}$ $\left(19 \% \mathrm{~d}^{-1}\right)$ suggests this is unlikely.

\section{Metal bioaccumulation and biomagnification in Menidia menidia}

When the calculated kinetic parameters from this study were entered into the biokinetic model, the predicted steady-state body burden $\left(C_{\mathrm{ss}}\right)$ was higher in the South Carolina population for Am, Cd, and Zn. The difference in predicted $C_{\mathrm{ss}}$ values for $\mathrm{Am}, \mathrm{Cd}$, and to a lesser extent $\mathrm{Zn}$ between the 2 populations can in part be attributed to higher AEs in South Carolina silversides. In Nova Scotia silversides, the rapid growth to overcome the shorter growing season and size-selective winter mortality is attributed to a higher ingestion rate and growth efficiency compared to South Carolina silversides (Conover \& Present 1990, Present \& Conover 1992). The higher growth rate may result in significant somatic growth dilution of accumulated metals, possibly reducing the metal concentration in the tissues. A field study focusing on the growth rate of Atlantic salmon has shown that Hg burdens are lower in faster growing fish, and this is attributed to somatic growth dilution (Ward et al. 2010). Many bioaccumulation studies do not consider growth rate in the biokinetic model, as the value is usually small compared to the efflux rate (Luoma \& Rainbow 2005). However, for juvenile Atlantic silversides, the rapid growth rate must be included to predict accurate body burdens. For $\mathrm{MeHg}$ and $\mathrm{Se}$, the higher ingestion rate in Nova Scotia silversides is offset by the higher growth rate, resulting in comparable $C_{\mathrm{ss}}$ values to those in South Carolina silversides. Nova Scotia silversides had a higher Hg(II) body burden, which can be attributed to a higher $\mathrm{Hg}(\mathrm{II}) k_{\mathrm{ef}}$ in the South Carolina population. Our $C_{\mathrm{ss}}$ values for each metal are comparable to the findings of other studies (Baines et al. 2002, Pickhardt et al. 2006, Mathews \& Fisher 2009).

For $\mathrm{Cd}, \mathrm{Hg}(\mathrm{II}), \mathrm{MeHg}$, and $\mathrm{Zn}$, the diet contributed to $>96 \%$ of the metal body burden. This is consistent with the results of other studies using fish fed zooplankton and fish prey (Xu \& Wang 2002, Pickhardt et al. 2006, Mathews \& Fisher 2009) for Cd, MeHg, and Zn. However, Pickhardt et al. (2006) noted that diet contributed 73 to $88 \%$ of the $\mathrm{Hg}(\mathrm{II})$ burden in mosquitofish, and 40 to $55 \%$ in redear sunfish, significantly lower than our calculated values. Differences between the 2 studies can be traced to the much higher $k_{\mathrm{u}}$ values for $\mathrm{Hg}$ (II) observed for mosquitofish and redear sunfish than we found for Atlantic silversides. Due to the low particle reactivity of selenite in the dissolved phase, we predict that $100 \%$ of Se is accumulated from the diet, consistent with other findings (Xu \& Wang 2002, Stewart et al. 2010). Am was the only metal where the aqueous phase had a large influence on steady-state body burden due to its very low AE, as also noted for other fish species (Mathews \& Fisher 2009). Water quality criteria need to recognize that dietary uptake is the dominant exposure route for most metals in marine fish.

The Atlantic silverside is not a commercially harvested fish, but it represents an important link between lower trophic levels and its predators. Studies have shown that juvenile silversides primarily feed on copepods (Adams 1976, Gilmurray \& Daborn 1981), and are preyed upon by piscivorous fish and sharks (Hartman \& Brandt 1995, Rountree \& Able 1996, Buckel et al. 1999). Of the metals examined in both silverside populations, Am, Hg(II), and Se are not expected to biomagnify (TTFs < 1) due to relatively low assimilation and high elimination rates (resulting in a short biological half-life). This is consistent with the findings of $\mathrm{Xu} \&$ Wang (2002), Wang \& Wong (2003), Mathews \& Fisher (2008a,b), and Mathews et al. (2008). MeHg is clearly expected to biomagnify (TTF $>1$ ), due to high assimilation and low elimination, as noted in other estuarine and marine fish (Wang \& Wong 2003, Pickhardt et al. 2006, Mathews \& Fisher 2008a). Zn was shown to biomagnify slightly in both populations, and $\mathrm{Cd}$ in the smaller South Carolina fish. Some studies have shown that $\mathrm{Zn}$ is not expected to biomagnify (Mathews \& Fisher 2008b, Mathews et al. 2008), while others have predicted $\mathrm{Zn}$ will if the ingestion rate and assimilation efficiency are high enough (Xu \& Wang 2002, Mathews et al. 2008). TTF could also be a function of body size: Zhang \& Wang (2007) noted that as body size increased, the TTF of Zn decreased. Cd has been found to biomagnify in freshwater fish (Croteau et al. 2005), but not in estuarine and marine fish (Xu \& Wang 2002, Mathews \& Fisher 2008a,b). Apart from that of $\mathrm{Hg}(\mathrm{II})$, TTFs were slightly higher in South Carolina silversides, an observation we attribute to 
higher AEs in South Carolina silversides (except $\mathrm{MeHg}$ ) and a higher growth rate in Nova Scotia silversides resulting in somatic growth dilution in juvenile Menidia menidia.

Acknowledgements. This research was funded by the SERDP W912HQ06C0014/W74RDV53574241 and NSF Award No. 0549370. We thank D. Conover for providing the fish and helpful comments; R. Cerrato for help with statistical analyses; W. Chamberlain and C. Knakal for fish maintenance; P. Pickhardt, S Baines, and S. Palma for laboratory assistance; and 3 anonymous reviewers for helpful comments on the manuscript.

\section{LITERATURE CITED}

Adams SM (1976) Feeding ecology of eelgrass fish communities. Trans Am Fish Soc 105:514-519

Andres S, Laporte JM, Mason RP (2002) Mercury accumulation and flux across the gills and the intestine of the blue crab (Callinectes sapidus). Aquat Toxicol 56:303-320

Baines SB, Fisher NS, Stewart R (2002) Assimilation and retention of selenium and other trace elements from crustacean food by juvenile striped bass (Morone saxatilis). Limnol Oceanogr 47:646-655

Bancon-Montigny C, Yang L, Sturgeon RE, Colombini V, Mester Z (2004) High-yield synthesis of milligram amounts of isotopically enriched methylmercury $\left(\mathrm{CH}_{3}{ }^{198} \mathrm{HgCl}\right)$. Appl Organomet Chem 18:57-64

Beck AD, Poston HA (1980) Effects of diet on survival and growth of the Atlantic silverside. Prog Fish-Cult 42: 138-143

Besser JM, Canfield TJ, La Point TW (1993) Bioaccumulation of organic and inorganic selenium in a laboratory food chain. Environ Toxicol Chem 12:57-72

Billerbeck JM, Schultz ET, Conover DO (2000) Adaptive variation in energy acquisition and allocation among latitudinal populations of the Atlantic silverside. Oecologia 122: 210-219

Billerbeck JM, Lankford TE, Conover DO (2001) Evolution of intrinsic growth and energy acquisition rates. I. Trade-offs with swimming performance in Menidia menidia. Evolution 55:1863-1872

Brzóska MM, Moniuszko-Jakoniuk J (2001) Interactions between cadmium and zinc in the organism. Food Chem Toxicol 39:967-980

Buckel JA, Fogarty MJ, Conover DO (1999) Foraging habits of bluefish, Pomatomus saltatrix, on the U.S. east coast continental shelf. Fish Bull 97:758-775

> Chang JW, Pai MC, Chen HL, Guo HR, Su HJ, Lee CC (2008) Cognitive function and blood methylmercury in adults living near a deserted chloroalkali factory. Environ Res 108:334-339

Cochran JK, Livingston HD, Hirschberg DJ, Surprenant LD (1987) Natural and anthropogenic radionuclide distributions in the northwest Atlantic Ocean. Earth Planet Sci Lett 84:135-152

Conover DO, Present TMC (1990) Countergradient variation in growth rate: compensation for length of the growing season among Atlantic silversides from different latitudes. Oecologia 83:316-324

Conover DO, Ross MR (1982) Patterns in seasonal abundance, growth and biomass of the Atlantic silverside, Menidia menidia, in a New England estuary. Estuaries 5:275-286

$>$ Croteau MN, Luoma SN, Stewart AR (2005) Trophic transfer of metals along freshwater food webs: evidence of cad- mium biomagnification in nature. Limnol Oceanogr 50: 1511-1519

Eisler R (1985) Selenium hazards to fish, wildlife, and invertebrates: a synoptic review. US Fish Wildl Serv Biol Rep 85 (1.5)

Eisler R (1993) Zinc hazards to fish, wildlife, and invertebrates: a synoptic review. US Fish Wildl Serv Biol Rep 10

> Fisher NS, Reinfelder JR (1991) Assimilation of selenium in the marine copepod Acartia tonsa studied with a radiotracer ratio method. Mar Ecol Prog Ser 70:157-164

Fisher NS, Reinfelder JR (1995) The trophic transfer of metals in marine systems. In: Tessier A, Turner DR (eds) Metal speciation and bioavailability in aquatic systems. Wiley, New York, NY, p 363-406

Fisher NS, Teyssié JL, Fowler SW, Wang WX (1996) Accumulation and retention of metals in mussels from food and water: a comparison under field and laboratory conditions. Environ Sci Technol 30:3232-3242

Fisher NS, Stupakoff I, Sañudo-Wilhelmy S, Wang WX, Teyssié JL, Fowler SW, Crusius J (2000) Trace metals in marine copepods: a field test of a bioaccumulation model coupled to laboratory uptake kinetics data. Mar Ecol Prog Ser 194:211-218

> Francesconi KA, Lenanton RCJ (1992) Mercury contamination in a semi-enclosed marine embayment: organic and inorganic mercury content of biota, and factors influencing mercury levels in fish. Mar Environ Res 33:189-212

Franklin NM, Glover CN, Nicol JA, Wood CM (2005) Calcium/cadmium interactions at uptake surfaces in rainbow trout: waterborne versus dietary routes of exposure. Environ Toxicol Chem 24:2954-2964

Gilmurray MC, Daborn GR (1981) Feeding relations of the Atlantic silverside Menidia menidia in the Minas Basin, Bay of Fundy. Mar Ecol Prog Ser 6:231-235

Guallar E, Sanz-Gallardo MI, van't Veer P, Bode P and others (2002) Mercury, fish oils, and the risk of myocardial infarction. N Engl J Med 347:1747-1754

Guillard RRL, Ryther JH (1962) Studies of marine planktonic diatoms I. Cyclotella nana Hustedt, and Detonula confervacea (Cleve). Can J Microbiol 8:229-239

> Hammerschmidt CR, Fitzgerald WF (2006) Bioaccumulation and trophic transfer of methylmercury in Long Island Sound. Arch Environ Contam Toxicol 51:416-424

> Hartman KJ, Brandt SB (1995) Trophic resource partitioning, diets, and growth of sympatric estuarine predators. Trans Am Fish Soc 124:520-537

IAEA (International Atomic Energy Agency) (2004) Sediment distribution coefficients and concentration factors for biota in the marine environment. IAEA Tech Rep Ser 422, Vienna

> Imura N, Sukegawa E, Pan SK, Nagao K, Kim JY, Kwan T, Ukita T (1971) Chemical methylation of inorganic mercury with methylcobalamin, a vitamin $B_{12}$ analog. Science 172: 1248-1249

Jackson CS, Sneddon J, Heagler MG, Lindow AG, Beck JN (2003) Use of flame atomic absorption spectrometry and the effect of water chemistry for the study of the bioaccumulation of cadmium in Menidia beryllina (cope), the tidewater silverside. Microchem J 75:23-28

Jeffree RA, Warnau M, Teyssié JL, Markich SJ (2006) Comparison of the bioaccumulation from seawater and depuration of heavy metals and radionuclides in the spotted dogfish Scyliorhinus canicula (Chondrichthys) and the turbot Psetta maxima (Actinopterygii: Teleostei). Sci Total Environ 368:839-852

Jessop BM (1983) Aspects of the life history of the Atlantic silverside (Menidia menidia) of the Annapolis River, Nova Scotia. Can Manuscr Rep Fish Aquat Sci No 1694 
Johnson MS (1975) Biochemical systematics of the Atherinid genus Menidia. Copeia 1975:662-691

Karimi R, Chen CY, Pickhardt PC, Fisher NS, Folt CL (2007) Stoichiometric controls of mercury dilution by growth. Proc Natl Acad Sci USA 104:7477-7482

Kennish MJ (1997) Practical handbook of estuarine and marine pollution. CRC Press, Boca Raton, FL

Lankford TE, Billerbeck JM, Conover DO (2001) Evolution of intrinsic growth and energy acquisition rates. II. Tradeoffs with vulnerability to predation in Menidia menidia. Evolution 55:1873-1881

Lawson NM, Mason RP (1998) Accumulation of mercury in estuarine food chains. Biogeochemistry 40:235-247

Leaner JJ, Mason RP (2002) Methylmercury accumulation and fluxes across the intestine of channel catfish, Ictalurus punctatus. Comp Biochem Physiol C 132:247-259

Leaner JJ, Mason RP (2004) Methylmercury uptake and distribution kinetics in sheepshead minnows, Cyprinodon variegates, after exposure to $\mathrm{CH}_{3} \mathrm{Hg}$-spiked food. Environ Toxicol Chem 23:2138-2146

Luoma SN, Rainbow PS (2005) Why is metal bioaccumulation so variable? Biodynamics as a unifying concept. Environ Sci Technol 39:1921-1931

> Mason RP, Reinfelder JR, Morel FMM (1995) Bioaccumulation of mercury and methylmercury. Water Air Soil Pollut 80: 915-921

Mason RP, Reinfelder JR, Morel FM (1996) Uptake, toxicity, and trophic transfer of mercury in a coastal diatom. Environ Sci Technol 30:1835-1845

Mathews T, Fisher NS (2008a) Evaluating the trophic transfer of cadmium, polonium, and methylmercury in an estuarine food chain. Environ Toxicol Chem 27:1093-1101

Mathews T, Fisher NS (2008b) Trophic transfer of seven trace metals in a four-step marine food chain. Mar Ecol Prog Ser 367:23-33

Mathews T, Fisher NS (2009) Dominance of dietary intake of metals in marine elasmobranch and teleost fish. Sci Total Environ 407:5156-5161

Mathews T, Fisher NS, Jeffree RA, Teyssié JL (2008) Assimilation and retention of metals in teleost and elasmobranch fishes following dietary exposure. Mar Ecol Prog Ser 360: $1-12$

Ni IH, Wang WX, Tam YK (2000) Transfer of Cd, Cr and Zn from zooplankton prey to mudskipper Periophthalmus cantonensis and glassy Ambassis urotaenia fishes. Mar Ecol Prog Ser 194:203-210

Nieboer E, Richardson DHS (1980) The replacement of the nondescript term 'heavy metals' by a biologically and chemically significant classification of metal ions. Environ Pollut Ser B 1:3-26

Park PK, Kester DR, Duedall IW, Ketchum BH (1983) Radioactive wastes and the ocean: an overview. In: Park PK, Kester DR, Duedall IW, Ketchum BH (eds) Wastes in the ocean, Vol 3. Radioactive wastes in the ocean. John Wiley \& Sons, New York, NY, p 3-46

Pickhardt PC, Stepanova M, Fisher NS (2006) Contrasting uptake routes and tissue distributions of inorganic and methylmercury in mosquitofish (Gambusia affinis) and redear sunfish (Lepomis microlophus). Environ Toxicol Chem 25:2132-2142

Present TMC, Conover DO (1992) Physiological basis of latitudinal growth differences in Menidia menidia: Variation in consumption or efficiency? Funct Ecol 6:23-31

Reinfelder JR, Fisher NS (1991) The assimilation of elements ingested by marine copepods. Science 251:794-796

Reinfelder JR, Fisher NS (1994a) Retention of elements absorbed by juvenile fish (Menidia menidia, Menidia beryllina) from zooplankton prey. Limnol Oceanogr 39: 1783-1789

Reinfelder JR, Fisher NS (1994b) The assimilation of elements ingested by marine planktonic bivalve larvae. Limnol Oceanogr 39:12-20

- Reinfelder JR, Fisher NS, Luoma SN, Nichols JW, Wang WX (1998) Trace element trophic transfer in aquatic organisms: a critique of the kinetic model approach. Sci Total Environ 219:117-135

> Rouleau C, Block M (1997) Fast and high-yield synthesis of radioactive $\mathrm{CH}_{3}{ }^{203} \mathrm{Hg}(\mathrm{II})$. Appl Organomet Chem 11: $751-753$

Rountree RA, Able KW (1996) Seasonal abundance, growth, and foraging habits of juvenile smooth dogfish, Mustelus canis, in a New Jersey estuary. Fish Bull 94:522-534

> Rudd JWM, Furutani A, Turner MA (1980) Mercury methylation by fish intestinal contents. Appl Environ Microbiol 40:777-782

> Schultz ET, Conover DO (1997) Latitudinal differences in somatic energy storage: adaptive responses to seasonality in an estuarine fish (Atherinidae: Menidia menidia). Oecologia 109:516-529

Sosebee KA (1991) Life history of a southern population of the Atlantic silverside, Menidia menidia, and comparisons with other latitudes. MS thesis, Stony Brook University, NY

Stewart AR, Grosell M, Buchwalter D, Fisher NS and others (2010) Bioaccumulation and trophic transfer of selenium. In: Chapman PM, Adams WJ, Brooks ML, Delos CG and others (eds) Ecological assessment of selenium in the aquatic environment. SETAC Press, Pensacola, FL, p 92-137

$>$ Thomann RV (1981) Equilibrium model of fate of microcontaminants in diverse aquatic food chains. Can J Fish Aquat Sci 38:280-296

- Wang WX, Fisher NS (1996) Assimilation of trace elements and carbon by the mussel Mytilus edulis: effects of food composition. Limnol Oceanogr 41:197-207

Wang WX, Fisher NS (1998) Accumulation of trace elements in a marine copepod. Limnol Oceanogr 43:273-283

Wang WX, Wong RSK (2003) Bioaccumulation kinetics and exposure pathways of inorganic mercury and methylmercury in a marine fish, the sweetlips Plectorhinchus gibbosus. Mar Ecol Prog Ser 261:257-268

Wang WX, Fisher NS, Luoma SN (1996) Kinetic determinations of trace element bioaccumulation in the mussel Mytilus edulis. Mar Ecol Prog Ser 140:91-113

Ward DM, Nislow KH, Chen CY, Folt CL (2010) Rapid, efficient growth reduces mercury concentrations in streamdwelling Atlantic salmon. Trans Am Fish Soc 139:1-10

> Wood CM, Franklin NM, Niyogi S (2006) The protective role of dietary calcium against cadmium uptake and toxicity in freshwater fish: an important role for the stomach. Environ Chem 3:389-394

> Xu Y, Wang WX (2001) Individual responses of trace-element assimilation and physiological turnover by the marine copepod Calanus sinicus to changes in food quantity. Mar Ecol Prog Ser 218:227-238

> Xu Y, Wang WX (2002) Exposure and potential food chain transfer factor of $\mathrm{Cd}$, Se and $\mathrm{Zn}$ in marine fish Lutjanus argentimaculatus. Mar Ecol Prog Ser 238:173-186

Zhang L, Wang WX (2006) Significance of subcellular metal distribution in prey in influencing the trophic transfer of metals in a marine fish. Limnol Oceanogr 51:2008-2017

Zhang L, Wang WX (2007) Size-dependence of the potential for metal biomagnification in early life stages of marine fish. Environ Toxicol Chem 26:787-794

Submitted: April 6, 2010; Accepted: July 20, 2010

Proofs received from author(s): September 5, 2010 